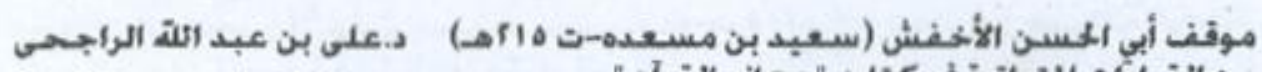

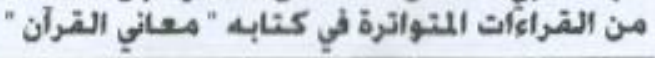

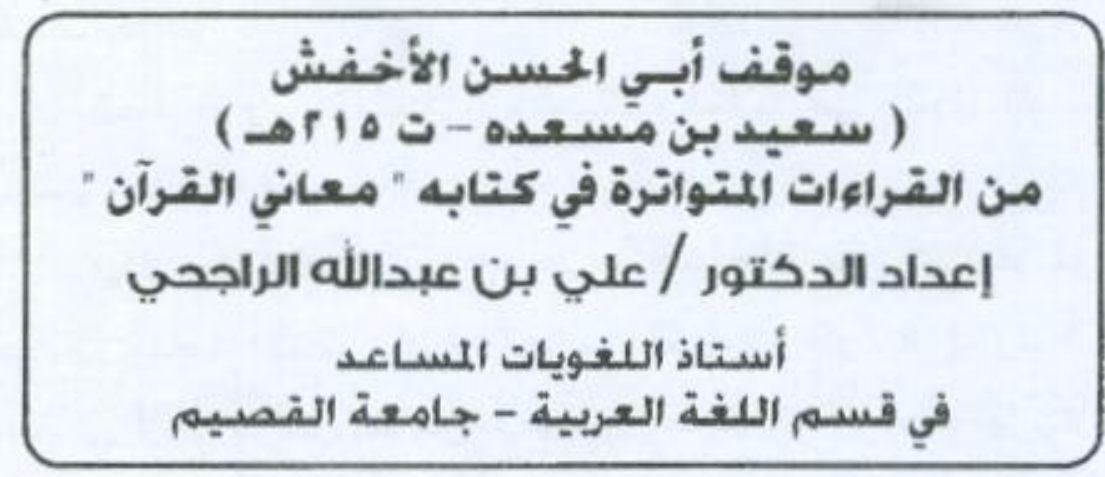

ملخحص البحتث :

هو بحث يقوم على المنهج اللوصفي الثحلولي ، فيبين عن موقف الأخفش أبي الحعن (سعيد بن مسعدة ت القرآن " اللر ائد في مصادر الدراسات اللغوية القر آنية ، حيث ألفيت للخفش في هذا الكتاب مواتف منباينة تجاه القزراهات القر أنية المتو ائزة ، من حيث القبول أو التزجيح و المفاضلة ، أو التضعيف ، وربما الردد أحياناً .

وقد الفتح هذا للبحث بنعريف موجز عن القرزاهات ودرجاتها وتاريخها ،

والفرق بينها وبين القرآن، ثُم ختم بيبان أهمبة القراءات المتّواتزة في الدرس اللغوي، وما ينبغي أي يكون عليه من ينصدى لدراسة القر اعات المنو اتزة . 
الحمد لله رب العالمين ، والصلاة والعلام على رسول الهل محمد بن

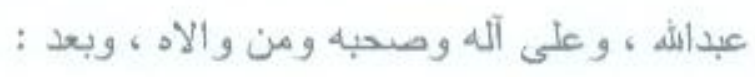

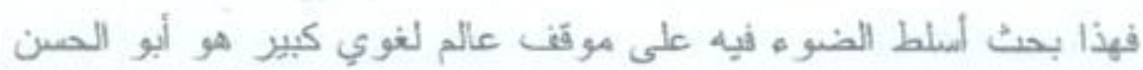

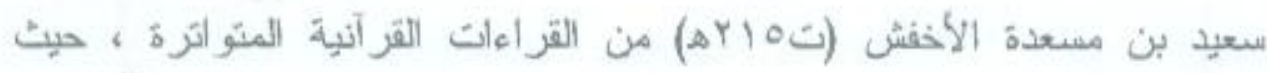

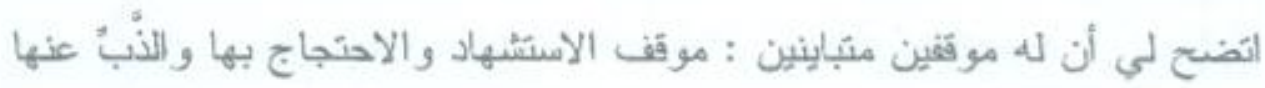

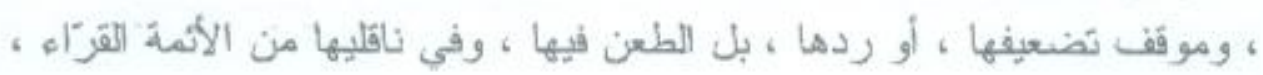
وموقف ثالث بينهما : وهو المفاضلة والتزجيح بينها . وقد انعقد هذا البحث حول القر اهات القَر آنبة المتو اترَة وموقفه منها دون

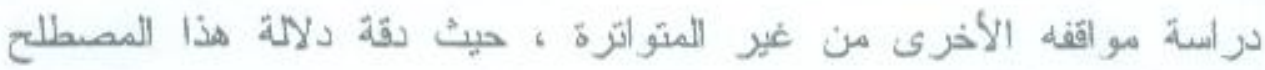

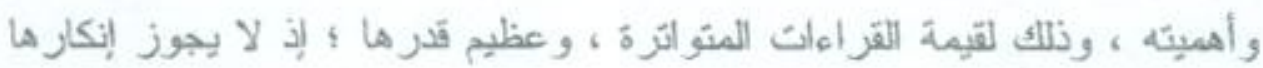

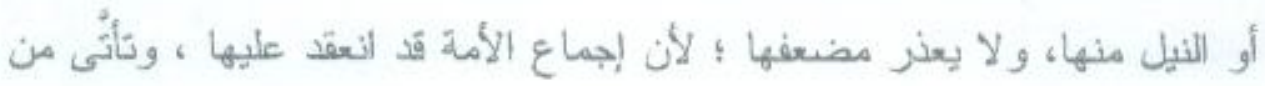

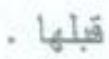

وقلد اقتضى البحث أن يقوم على مبحين وخاتمة :

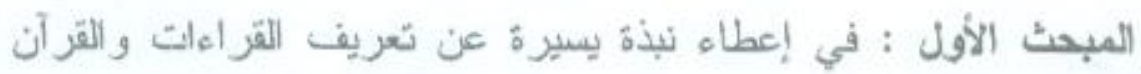

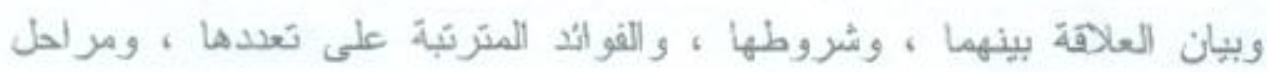
الئأليف فيها.

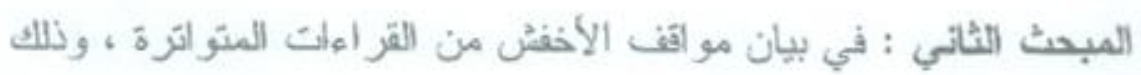

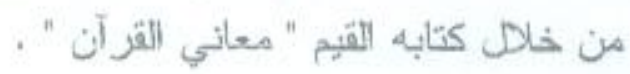

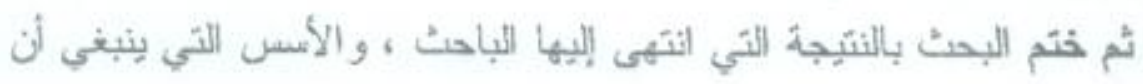

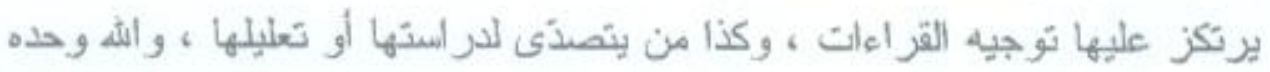

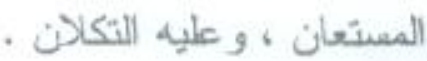




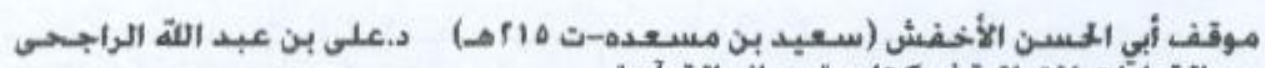

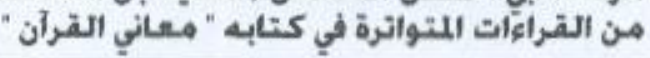

\section{المبحثث الأول}

في تعريف القراءات ، ودرجاتها وشـروطها

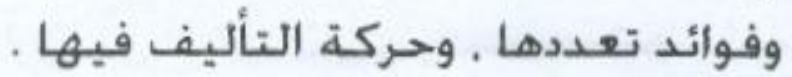

ا- تعريف القرآن :

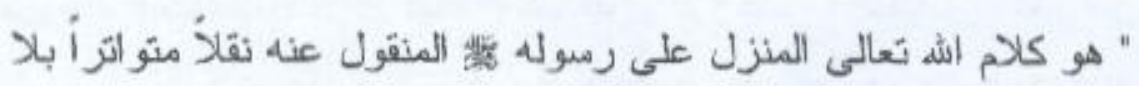

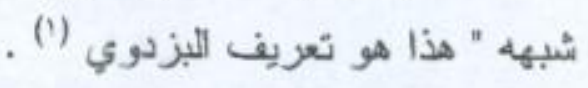

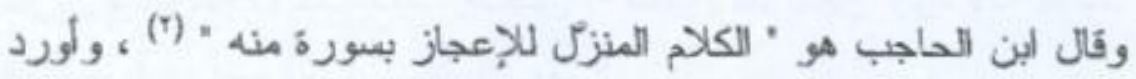

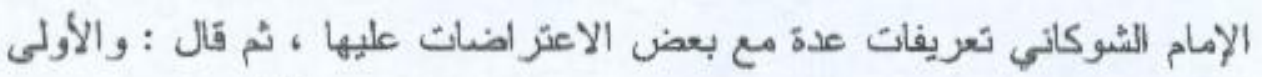

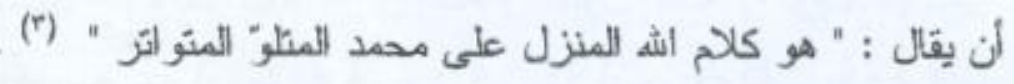
وكلها ذات دلالات منقاربة تحمل المعنى نفسه .

$$
\text { ا- تعريف القراءات : }
$$

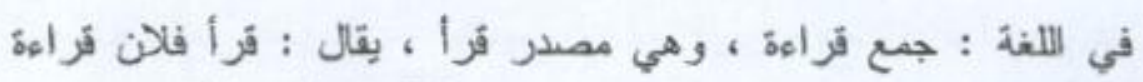

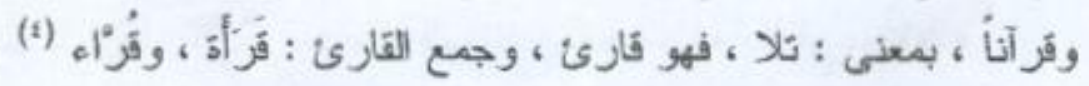

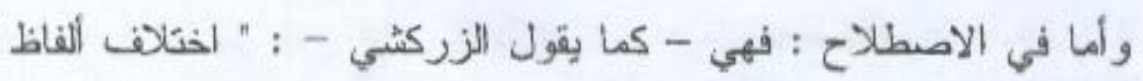

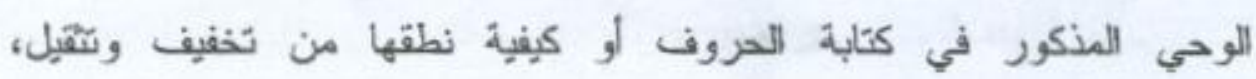

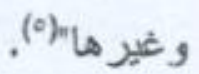

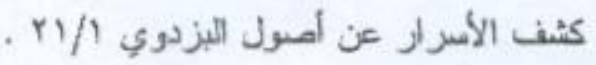

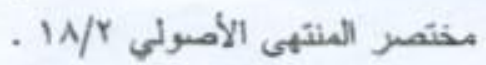

$$
\begin{aligned}
& \text { إرشاد الفحول .r. } \\
& \text { ينظر : اللسان ، و القاموس ، و الصداح ، مادة كرأ . }
\end{aligned}
$$

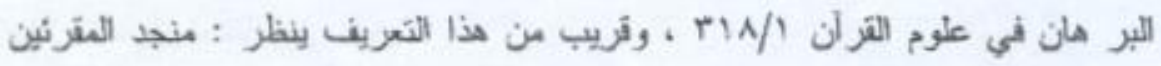

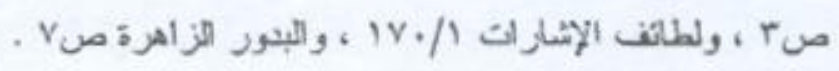




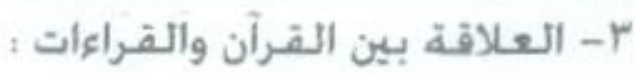

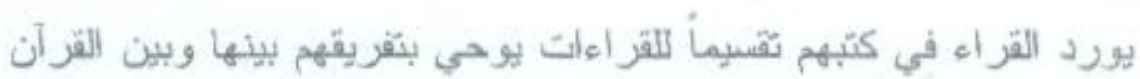

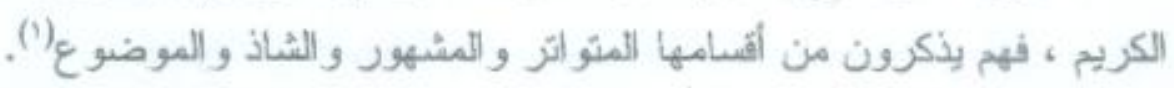

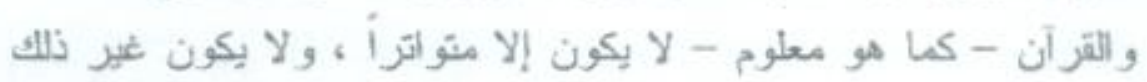

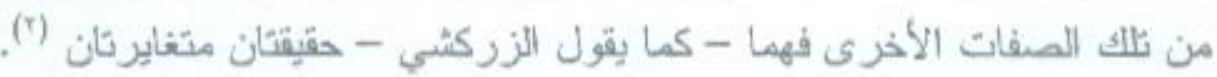

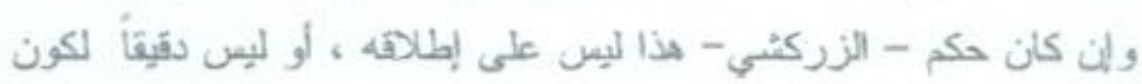

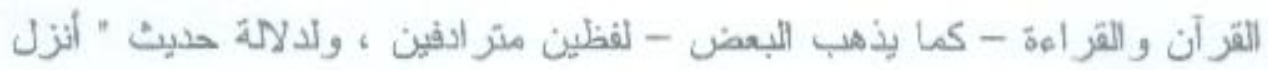

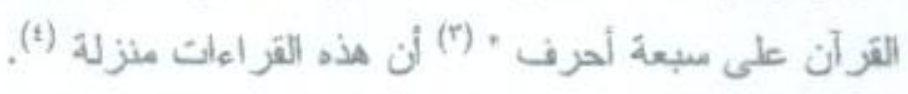

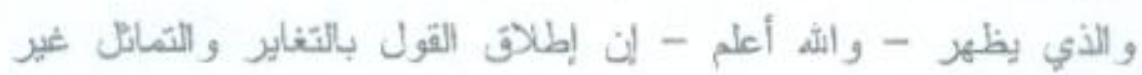

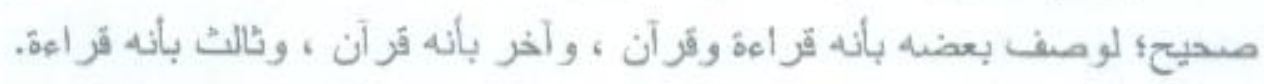

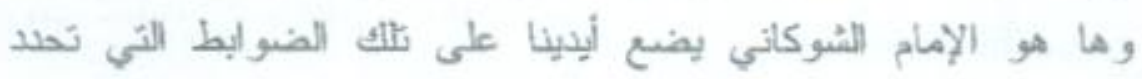

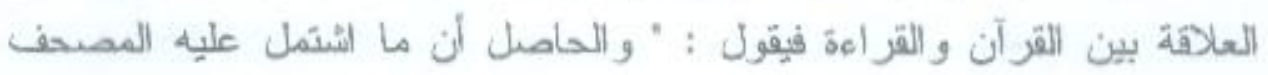

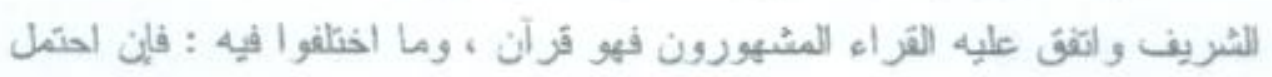

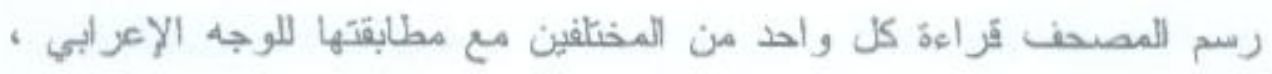

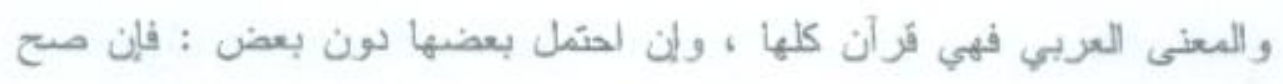

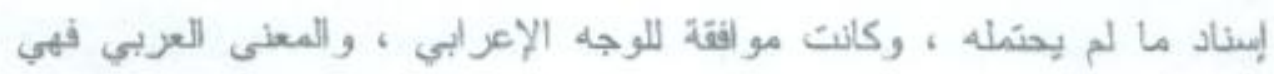

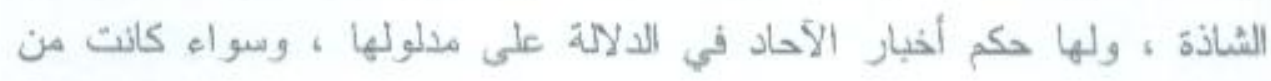

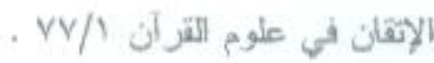

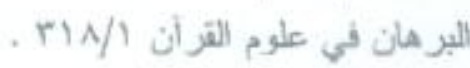

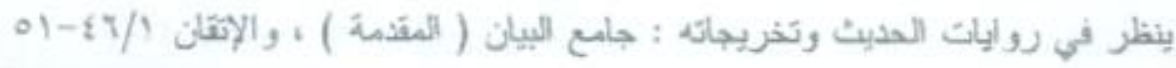

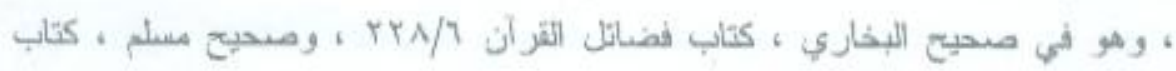

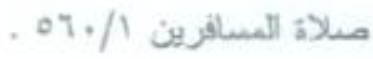

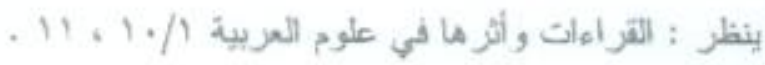


القر اءات الفبع أو من غيرها .

وأما ها لم يصح إيناده مما لم يحنمله الربم قليس بقرآن ورلا منزل منزلة أخبار الأحاد ، أما انتفاء كونه قر آناً فظاهر ، وأما اثنقاه تيزيله منزلة

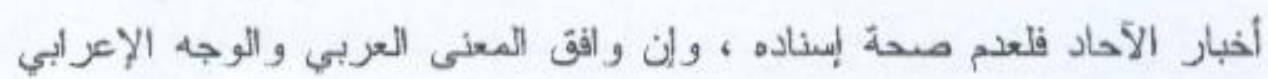

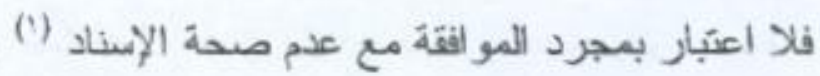
فهذه التفصيلات و الضوالبط تجعل في الأمر سعة بقبل معها الخلاف ، فقد يجيز أقوام قراعة لموافقتها -عندهم- وجهاً هن العربية ، ويردها آخرون

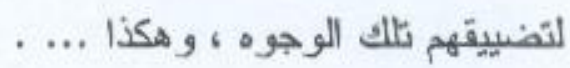

ع- شـروط القراءات الصسحيحة واللفوائد المترتبة على تنوعها : :

يقول الإمام أبو محمد مكي بن أبي طلاب القيسي (تVY\&ه) - عما يقبل

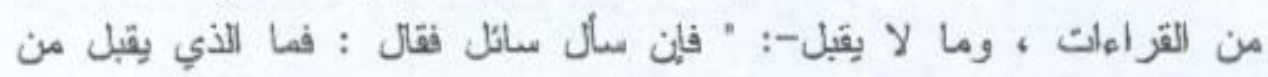
القزاءات الأن فيقزأ به، وما الذي لا يقبل ولا يقرأ به، وما الذي يقبل ولا

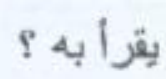

فالجواب : أن جمبع ما روي من القزاءلت على ثلانة أقسام : قسم يقرأ

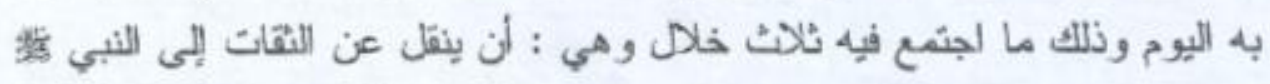
ويكون في وجهه في العربية التي نزل بها القر آن شائعاً ، ويكون مو افقاً لخط

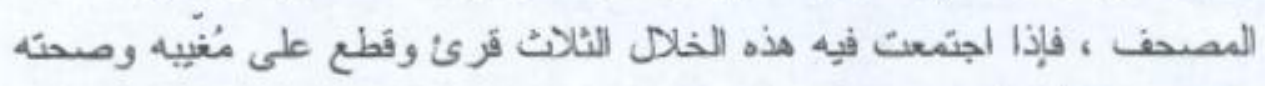

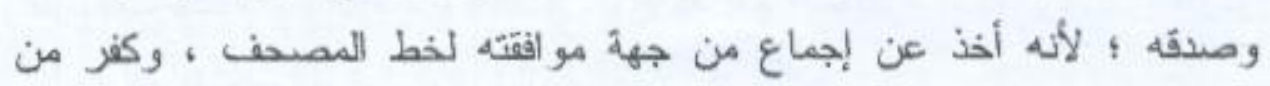
جحده.

والقسم الإني: ما صح نقله عن الأحاد، وصح وجهه في العربية، خالف 
لفظه خط المصحف ، فهذا يقبل ، ورلا يقز أ به لعلتين :

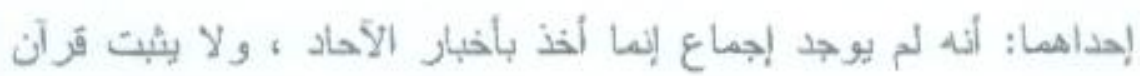
يقر أ بها بخبر الو الحد.

والعلة الثانية : أنه مخالف لما قد أجمع عليه ، فلا بقطع على مغيبه وصحته ، وما لم يقطع على صحته لا تجوز القز اعة به ، ولا بكهز من جحده، وبئسما صنع إذ جده. والقصم الثالث: هو ما نقله غير نقة، أو نقله ثقة ولا وجه له في العربية،

(1) " فهذا لا يقبل، و إن و افق خط المصدف: والمقبول منها في القشم الأول عنده هي- كا يقول أبو شامة

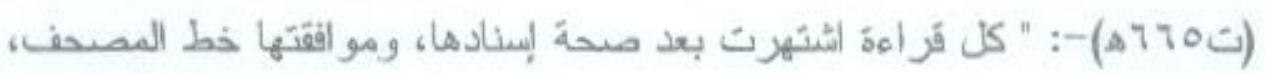
ولم تتكر من جهة العربية فهي القز أمة المعتمد عليها، وما عدا نلف فهو داخل في

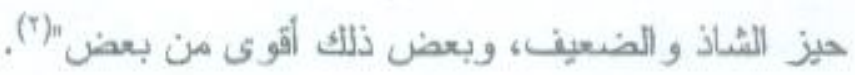

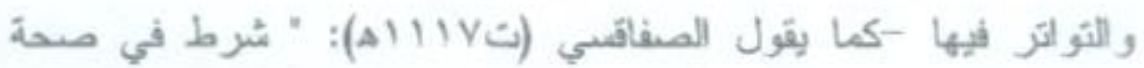

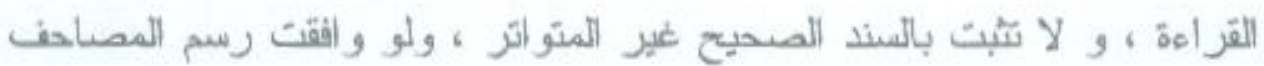

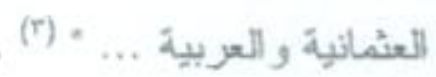

وعلى هذا النحو نجد في أجوبة أولنك العلماء شيئاً هن التباين أو الو

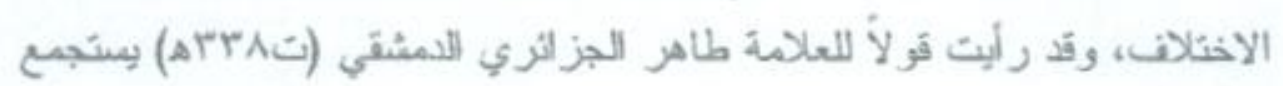

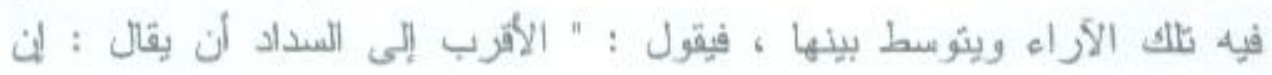
القزاعات المبع منواترة في الجملة ، ويوجد فيها المشهور والمزوي من طريث الآحاد المحفوفة بالقز أئن المفيدة للعلم .

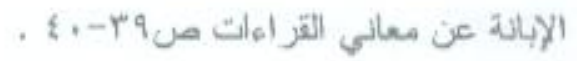

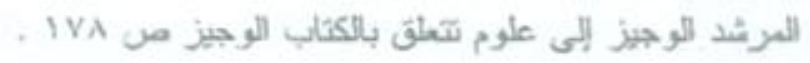

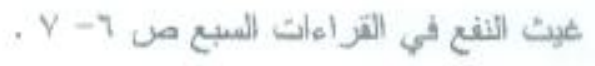




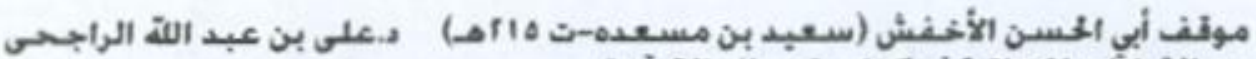

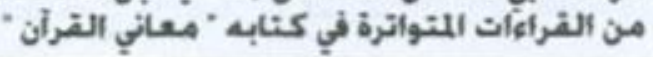

وأما المروي من طريق الآحاد المحضية فهو فيها نزر لا بكاد يذكر ،

وهو ما طعن فيه بعض الأمة ، ولم يكن عنه جواب سليد" (1) وهذا القول من الجزائري هو ما يحمل عليه كلام العابقين عند تدبره

و إمعان للنظر فيه .

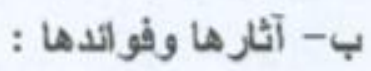

لتتوع القراعات آثار وفوائد جمة تتصل بالأحكام الثشرعية و الفقهية ، و اللغوية ، و إقامة الحجج و اللبر الهين على حفظ كتاب الله من التحريف و التغير ، وبيان فضل هذه الأمة باعتائها بنقل القزلن بقراءات على وجه التوائز ، ولعل هن أهمها مما قام عليه هذا اللبحث ما تركتها هذه القز اعات من آنار في تطور الفكر اللغوي ، لاميما بعد اعتقاد اللغويين بصحة بلك القر اعات وبواتزرها حيث

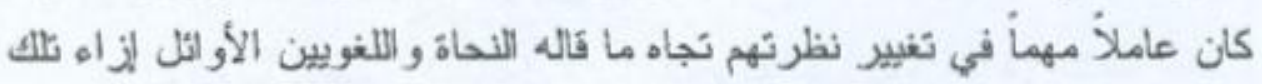
القز اهلت في تقعيدهم وتأصيلهم وأفيسنه ، و على رأس ذلك مصطلحات الأصول

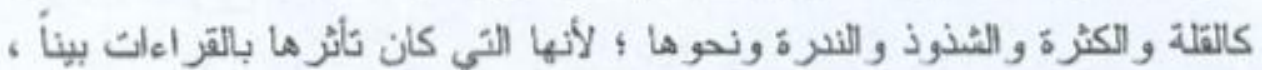
بل اليجابياً .

وفيها من توميع الله على عباده ، ورفع الحرج عنهم ؛ إل كانت لغات العزب مختفة، وقد لا يعنطيع صاحب اللغة اللتحول عن لغته إلا بعد كلفة ومنقانة.

$$
\text { ه- التأليف في التراءات : }
$$

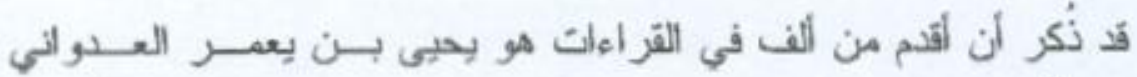
، حبث جمع ما روي من لختلاف الذاس فيما و افق الخط (r).
(r) (A) ( 9 ت

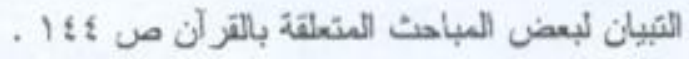

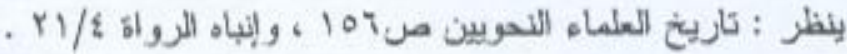

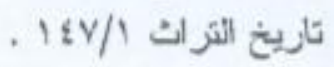




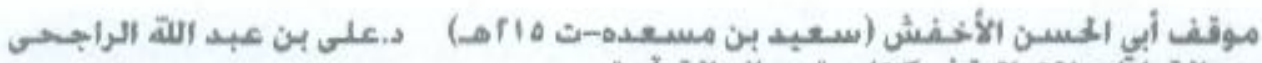

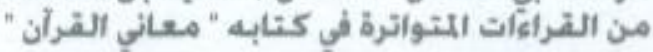

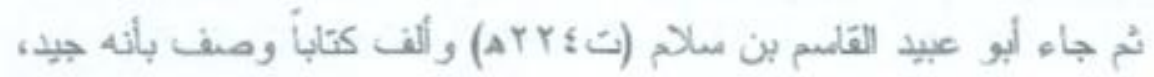

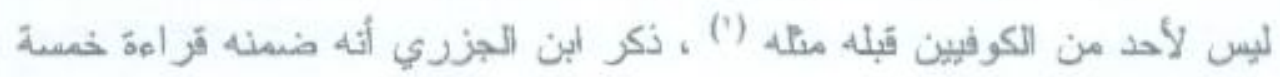

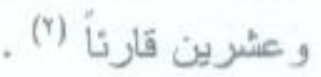

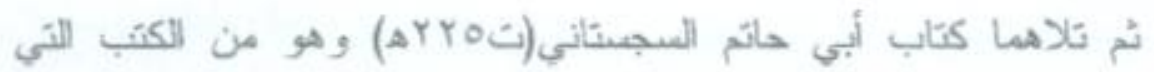
يفتخر بها أهل البصرة: - كما نكر ذلك الفيروز آبادي - بقوله : " ولأهل البصرة أربعة كتب يفتخرون بها على أهل الأرض كتاب (التعن) للخليل، و (كتاب سيبويه) ، وكتاب ( الحيولن ) للجاحظ ، وكتاب أبي حاتم في

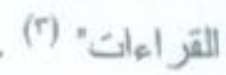

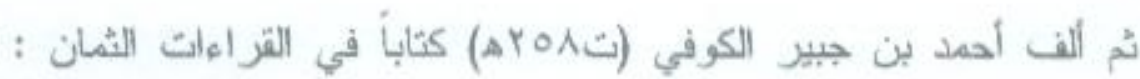

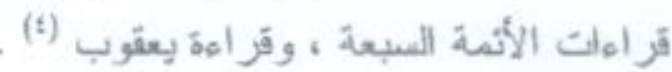
وتبعهم القاضي إنماعيل بن إسحاق المالكي (ت بrAYه) بكتاب جمع فيه

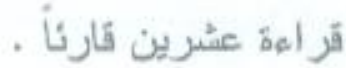

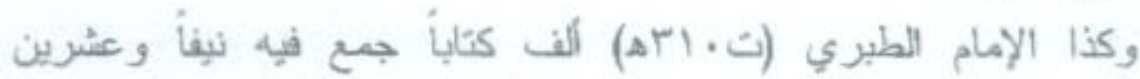

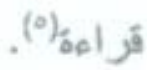
تم توجها ابن مجاهد (ت ع بrه) بكتابها ( المبعة ) الذي كتب الشه له ذيوع الصنيت و القبول

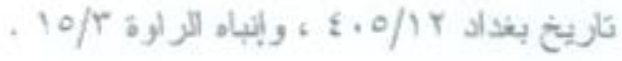

$$
\begin{aligned}
& \text { الأنشر بr/ }
\end{aligned}
$$

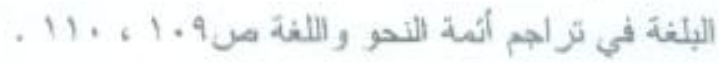

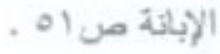

$$
\begin{aligned}
& \text { النشر }
\end{aligned}
$$




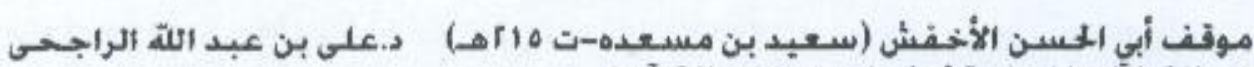

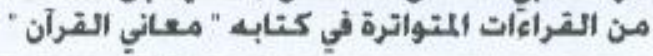

\section{المبستش النثانى}

شـروط اللقراءات المتواترة عند الأخـفش . ومـوقفه منهـا .

$$
\text { أوكٌُ : شـروطها : }
$$

إن من بيقثرئ كتاب " معاني القرآن " للكخفش ، وما أورده فيه من

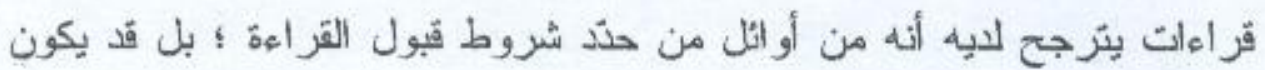
أولهم حسب علمي ، وهي الثروط الثلاثة سالفة الذكر ، وربما هي عنده أربعة ،

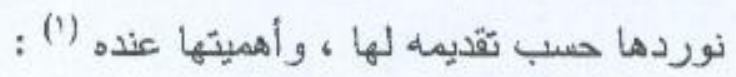
1- ثيوت الفراءة بالأكثرية .

و هذا الشرط يُعبئر عنه بـ " أخذ أكثر القُرَاء أو العامة منهم لها " ، وهو ما يقابل عند المنأخرين بمفهومه شرط شبوت اللهيند . ولقد تزدنت هذه العبارة ونحوها كثيرأ بما يؤكد اعتداده بهذا الشرط

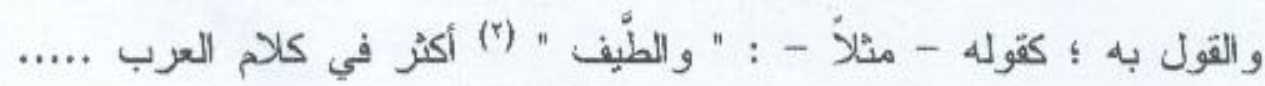
ونقرو ونان

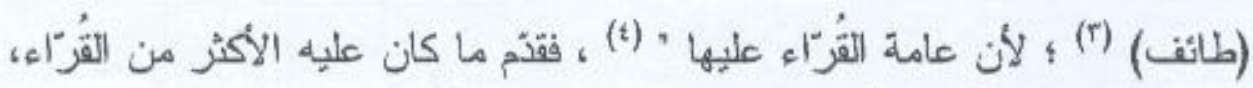
على ما كان فاشياً وكثير أ في العربية . وقوله : "وذلك أن العرب تحول الشيء من الهمزذ حتى يصير كبنات

وقد أشار إليها الككتور / عبد الأمير الورد في مقدهة تحقيقه للكتاب .

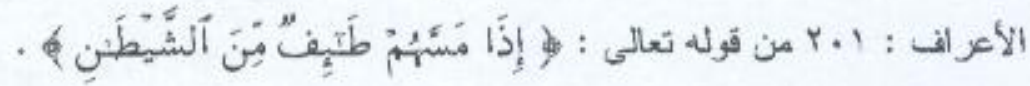
القز اعة بـ " طيف " لأبي عمرو ، و ابن كثير ، و الكسائي ، و القر اهة بـ " طائف " لثافع

، وعاصم ،و ابن عامر ، وحمزة .

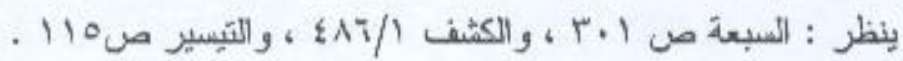

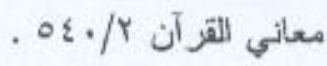




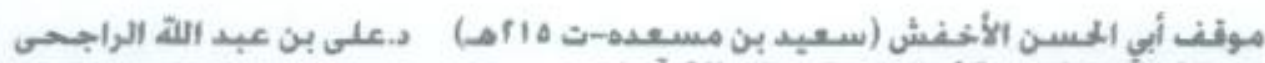

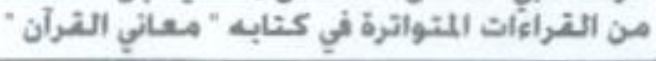

اللياه بيجنمون على ترك الهمزة نحو " المينّئة " ، و لا بكاد أحد يهمزها إلا في

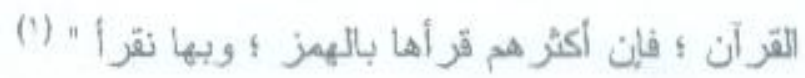

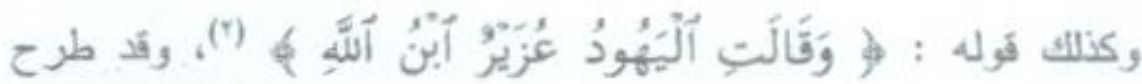
بعضهم اللتوين (r) ، ونلك رديء \& لأنه إنما يترك التتوين إذا كان الاسم يستغني

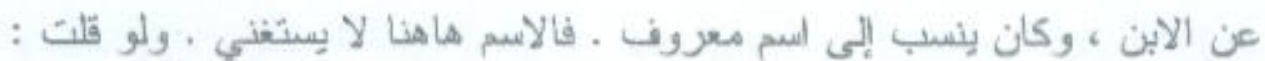

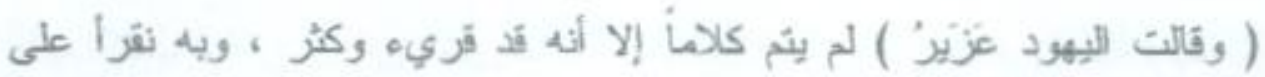
(i) ".... الحكائة

\section{:}

وهو الظظابط الذي لا يقل أهمية - عند الأخفش - عن سابقه ؛ بل ربما

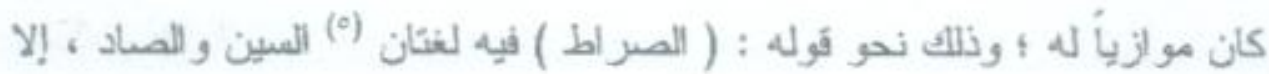

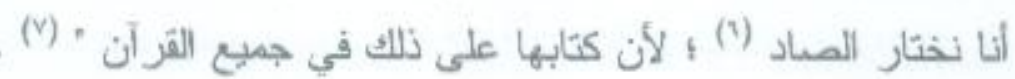

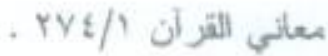

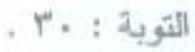

قرأ بالتنوين : عاصم و الكساتي ، وئر أبلا تتوين : ابن كثير ، ونافع ، وليو عمرو ؛

$$
\text { o s o }
$$

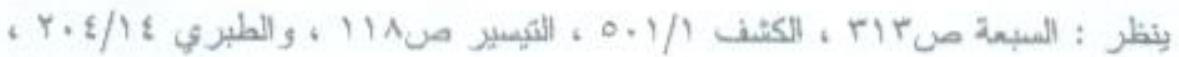

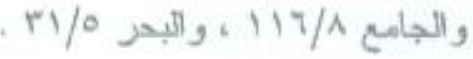

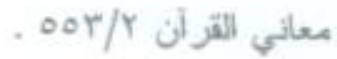

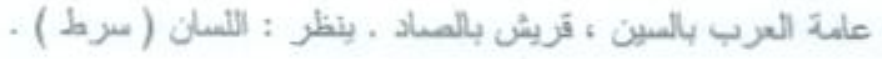

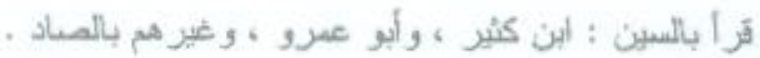

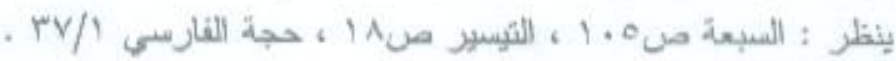

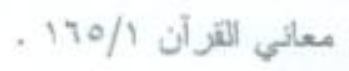




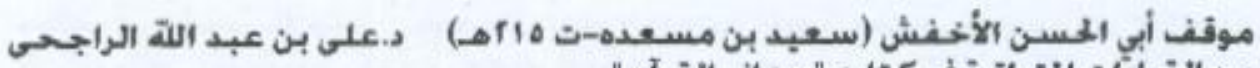

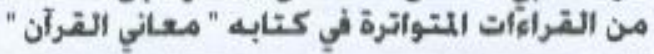

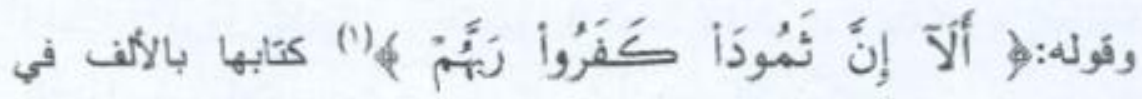

$$
\text { (ז)".... (1) }
$$

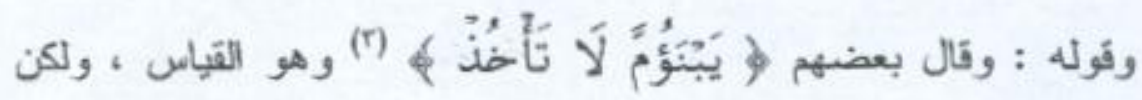

$$
\begin{aligned}
& \text { الكتاب ليست فيه ياء ؛ فلذلك كره هذا " (t) . ونحو ذلك من العبار ات (0) }
\end{aligned}
$$

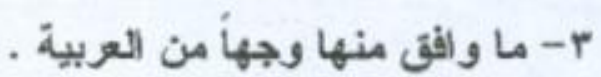

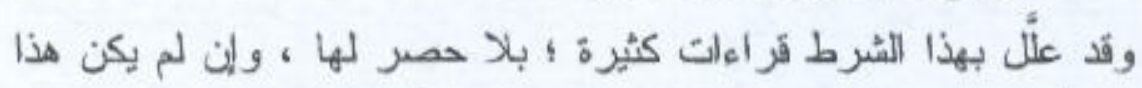
الشرط مقدماً عنده كتقديم الشرطين السابقين ؛ لأندا رأيناه فيما نقدم يقدم القزاءة

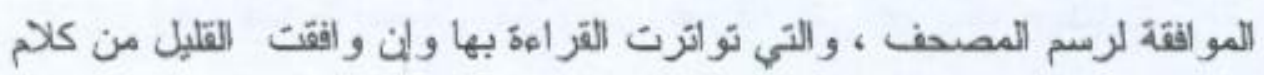

$$
\text { العزب }
$$

\section{ومن أملامة تعليله بعض القز اعات بهذا اللقرط ما جاء في توله :}

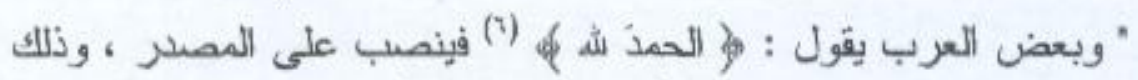

أنْ أصل الكلام عنده على قوله ( حمدأ لله ) يجعله بدلاً من اللفظ بالفعل .... وقد

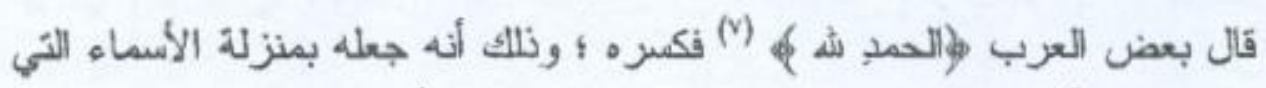
ليمت بمنمكنه ، ونلك أن الأسماه التئي ليست بمنمكنه تحرك أواخرها حركة

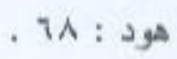

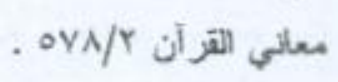

$$
\begin{aligned}
& \text {. 4 : : }
\end{aligned}
$$

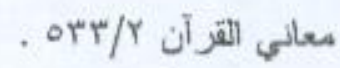

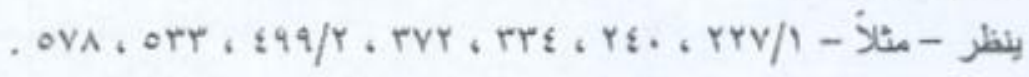

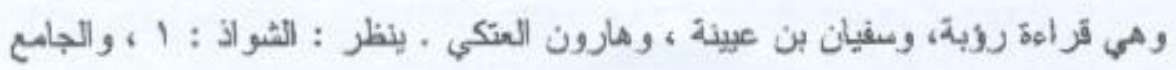

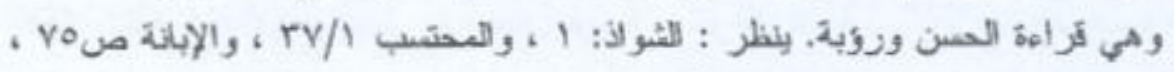

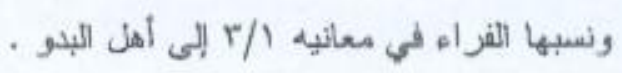




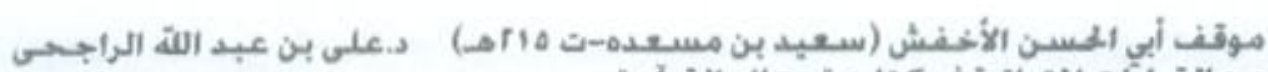

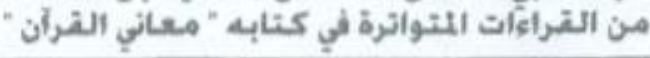

واحدة لا تزول علتها .... فشبهوا ( الحمد ) و هو السم مثمكن في هذه اللغة بهذه (1) الأسماء التي لليست بمنمكنه

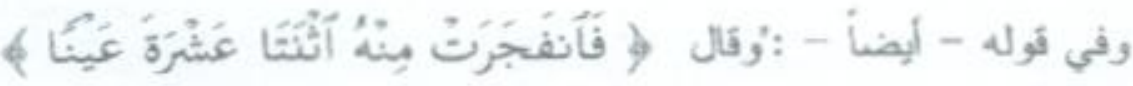

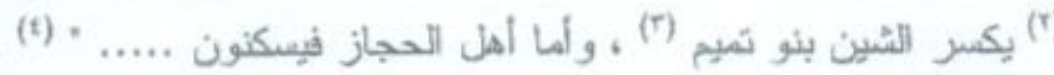

وقوله : " فكرز الفعل وقد يستغنى بأحدهما ، و هذا على لغنة الذين فالوا :

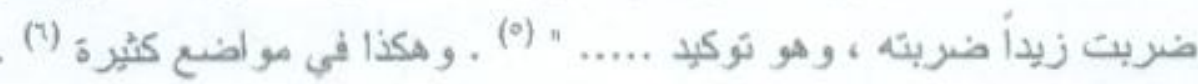

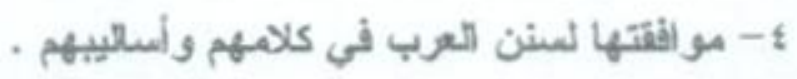

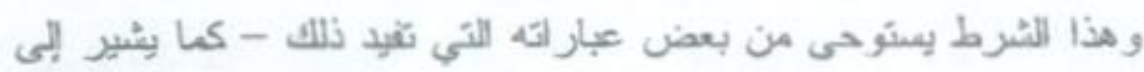

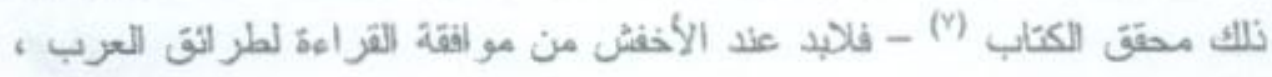
وإلا فإنها لا نكون ، أو لا يقرأ بها .

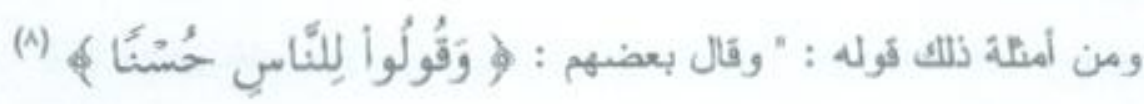
يؤنثها ولم ينونها ، و هذا لا يكاد يكون ؛ لأن ( الحسنى ) لا يتكلم بها إلا بالالف

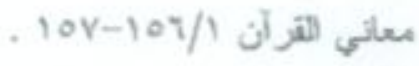

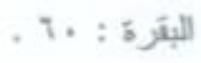

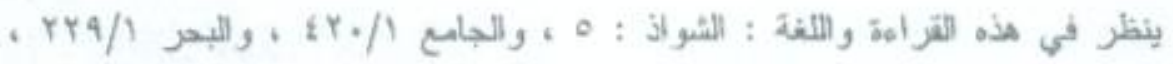

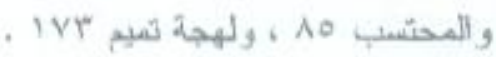

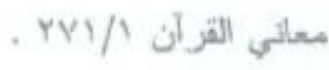

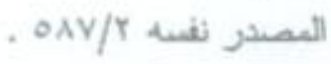

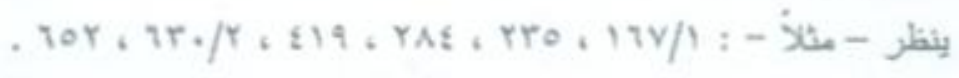

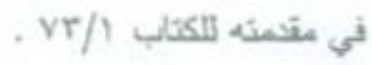

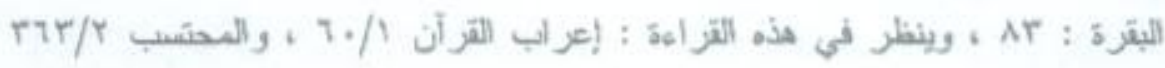

$$
\text { وهي من الشُولاك. }
$$




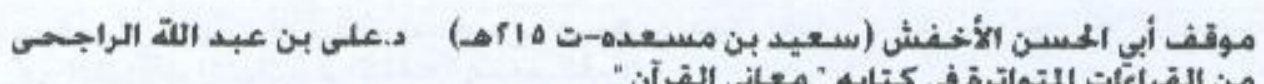
من القراءأت المتواترة في كتابه " معاني الثرآن"

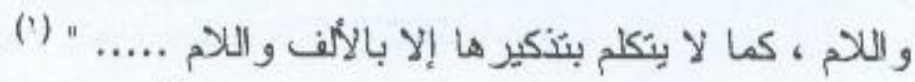

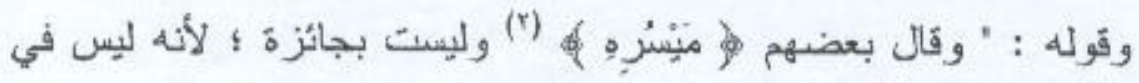

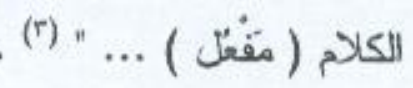

وبهذه الضوابط والشورط التي نكرها بصريح العبارات يتبين أن فئن

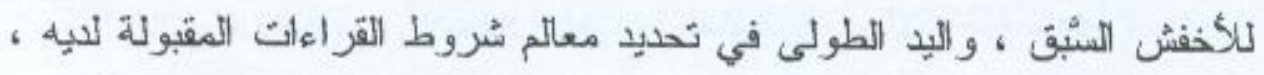

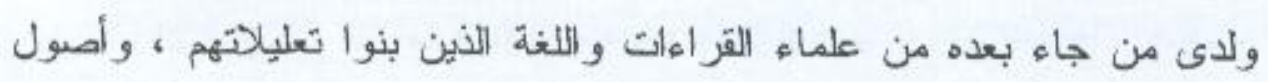

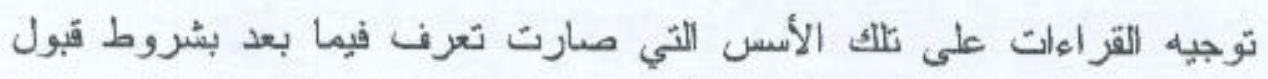

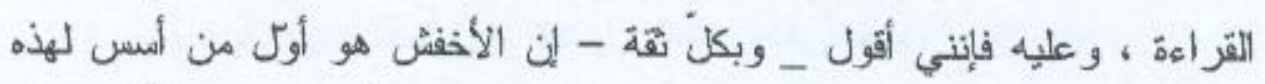

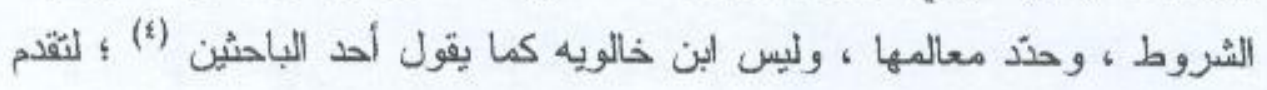

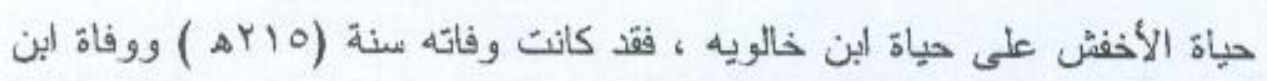

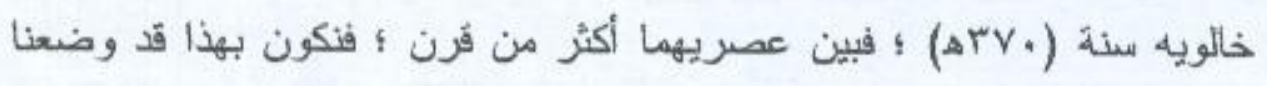

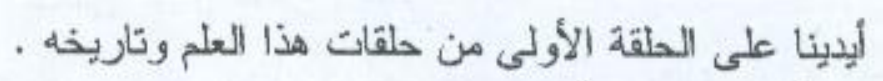

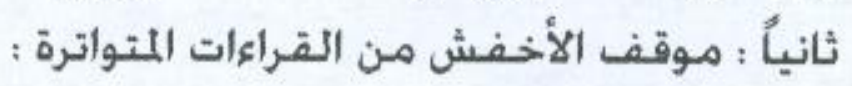

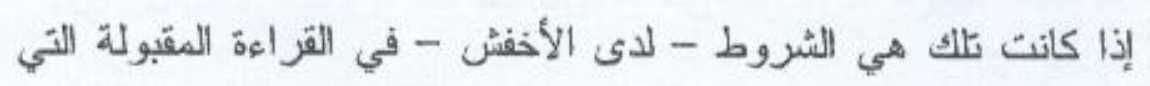

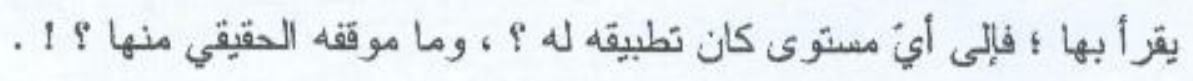

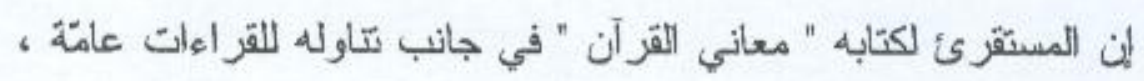

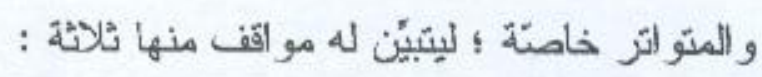

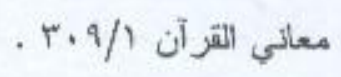

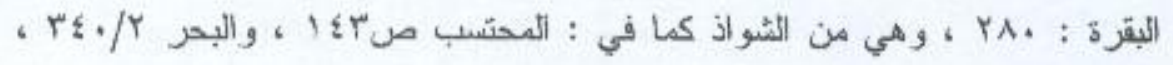

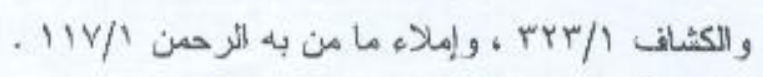

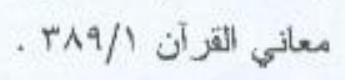

هو الدكتور : عبدالهادي الفضلي في كتابه : القراءات القرآئية ثاريخ وتعريف

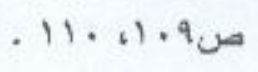


أحدها : الاعتداد بالقر اعة المتو ائزة و الاصتشهياد بها .

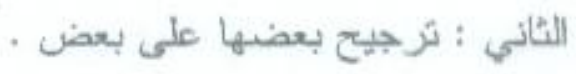

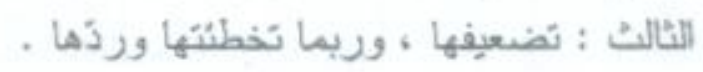

ومن الأمثلة على هذه المو القف :

الموقف الأكل : الاعتداد بالقر اعة المتواترة ، والاستشهاد بها .

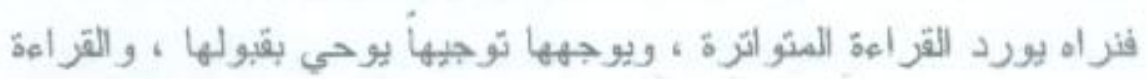

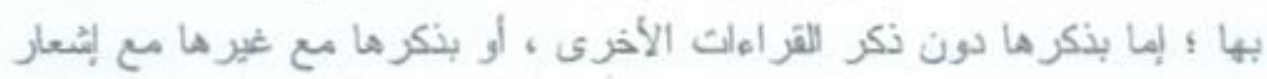

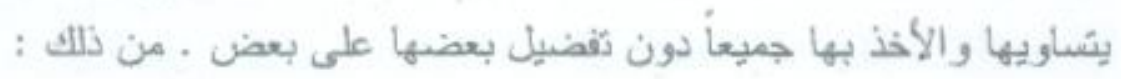

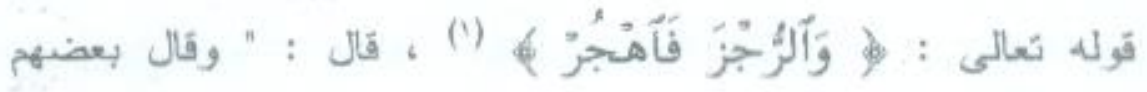

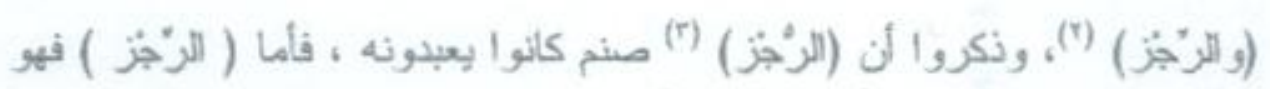

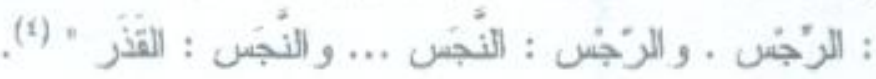
فهو يذكرها - هنا - على سبيل قبولها بالتشاوي ، ويعلل لكل واحدة

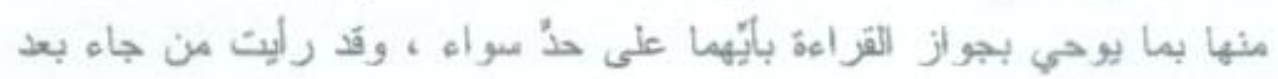

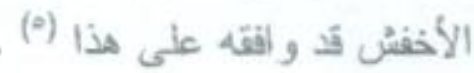

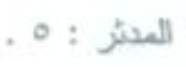

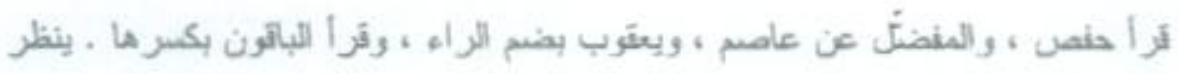

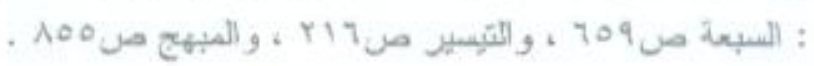

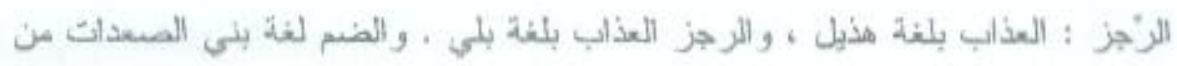

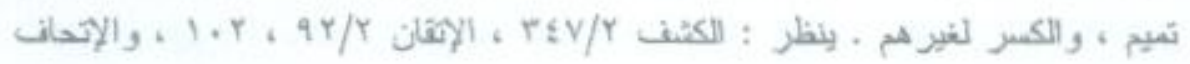
EVI Iنيل

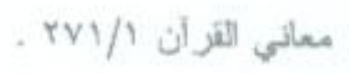

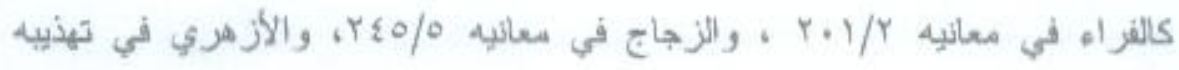

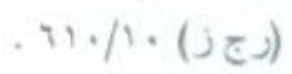




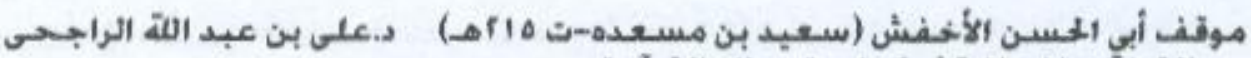

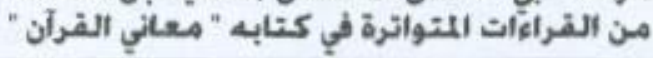

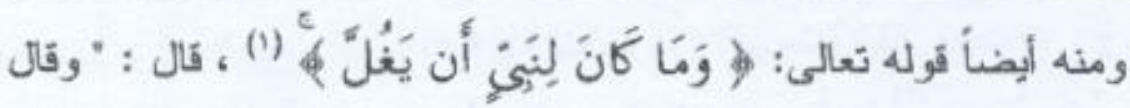

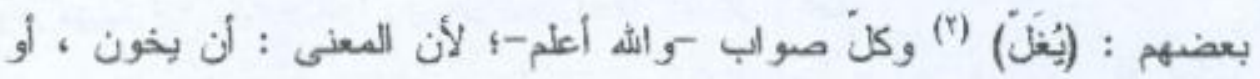

(T) : يُخان

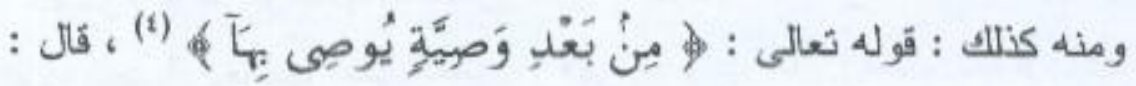

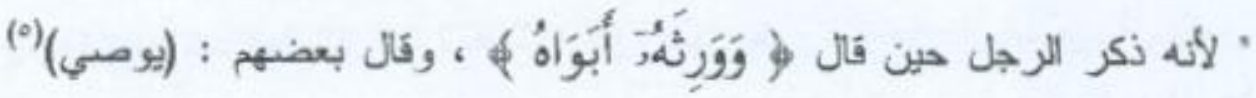

$$
\text { (v) "....... وكل حسن }
$$

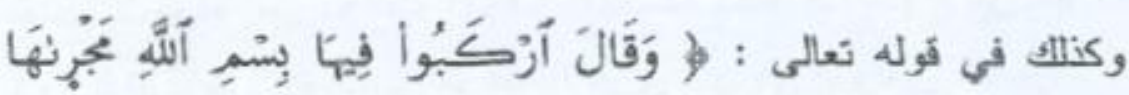

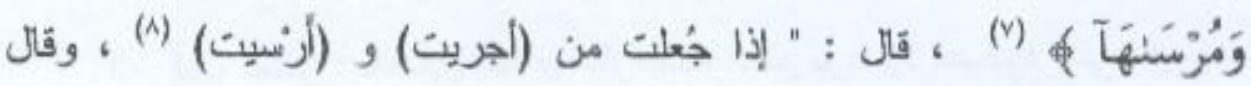

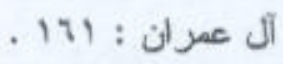

قرأ ابن كثير ، وأبو عمرو ، وعاصم بفتح الياء وضم الغين ، وقرأ الباتون بضم الياء

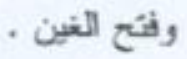

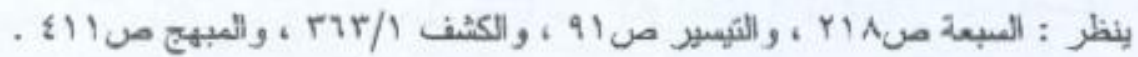

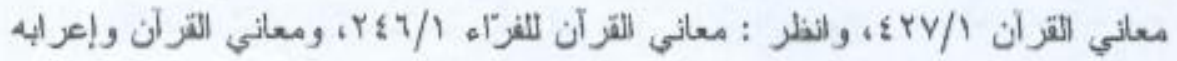

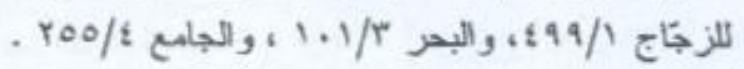

$$
\text { . }
$$

(0) قرأ ابن كثير، وابن عامر، و عاصم في رواية أبي بكر بفتح الصاديو مز أ الباقون بكسرها.

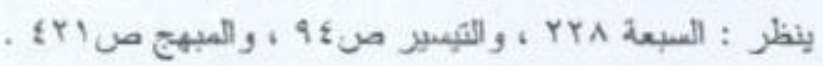

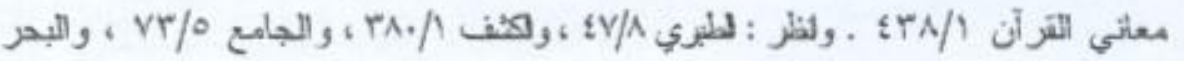

$$
\text { هو } 211 / 4
$$

قرأ ابن كثير ، ونافع ، وأبو عمرو ، وعاصم في رواية بضم المبم الأولى ، وقرا

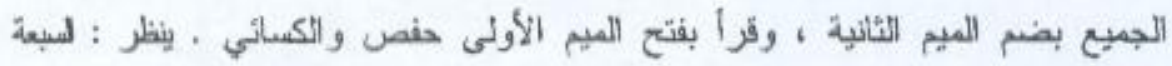

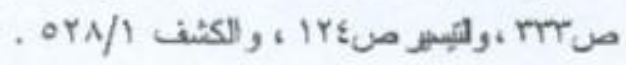




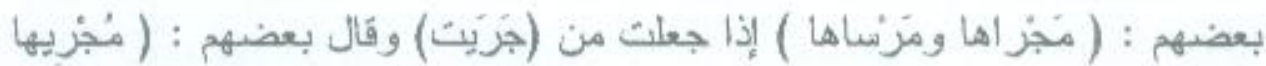

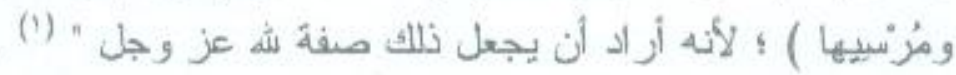
وهكذا - في مواضع منعددة - كانت تساوى عنده وجوه القزاءات المتو اتزة ؛ إما بوصفها بالحمن ، أو الصو اب كما مرّ ، أو التعليل لها جميعاً

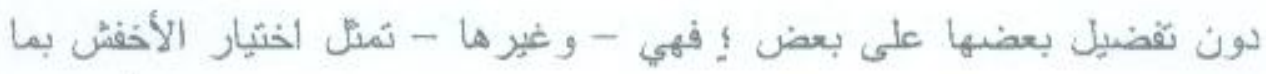
يتو افت مع ضو ابط القر اعة المقبولة وشروطها عنده ، وبما كان ينبغي أن يكون

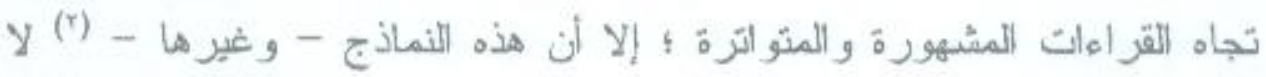

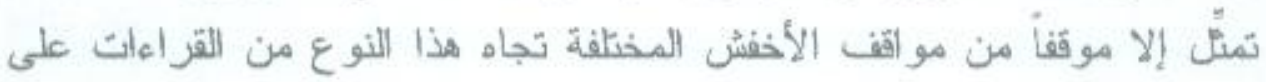
وجه الخصوص ، و وستثبين مو اقفه الأخرى منها في الموتفين اللتاليين .

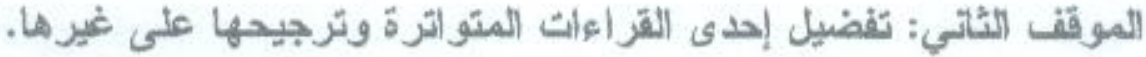

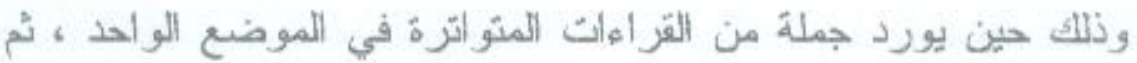

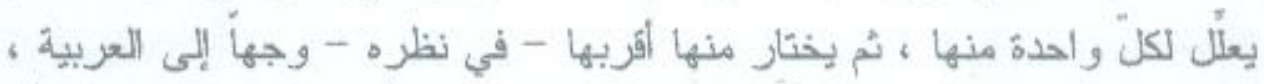

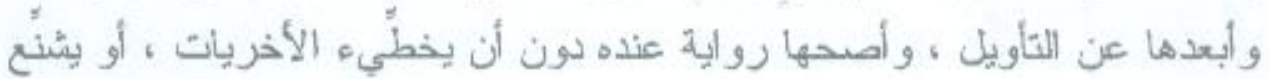

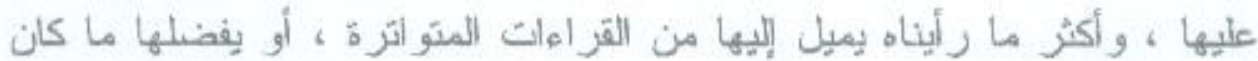

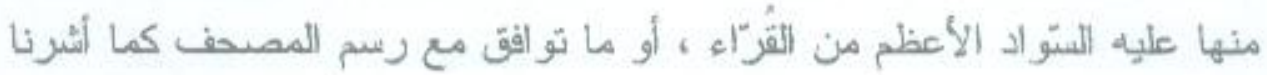
إلىى ذلك في مبحث شروط القزاهة عنده ، ورذا التزرجيح يعبزر عنه بعبارات

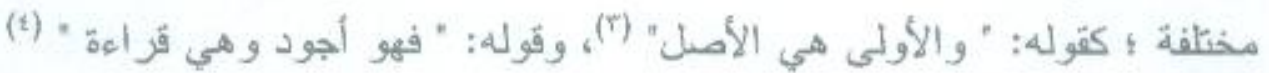

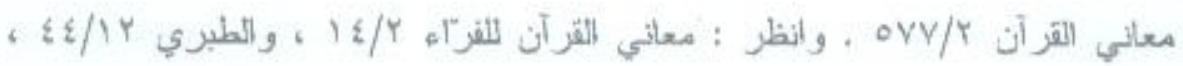

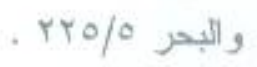

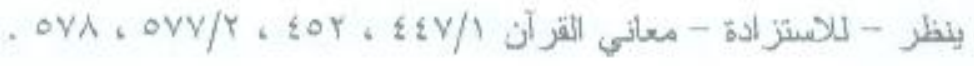

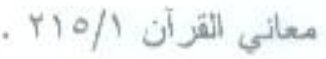

$$
\begin{aligned}
& \text { S }
\end{aligned}
$$




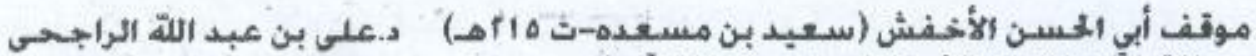 من القراءًات المتواترة في كتابه " معاني القرآن"}

وقوله : " و اللتضعيف القر اعة الجِيدة وبها نقر أ " (1) وقوله : " فأنت فيه أيضاً بالخيار إلا أن أحسنه في هذا الحذف ، وبها لوبها

نقز أ " (r) (ن)

وكل ما يبل من العبار ات على الثرجيح و الاختيار فإنه يسنعمله .

ولإيضاح نورد بعض النماذج ، ومنها حديثه عن القر اعات في (يذرهم)

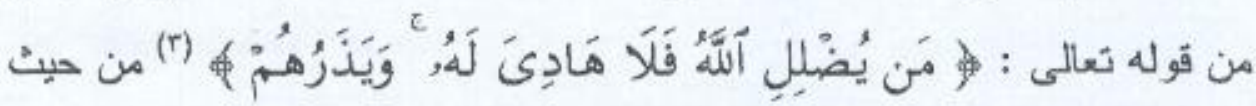
الرفع أو الجزم (ء) ؛ فقال : " ...... فجزم (يذر"هم ) على أنه عطف على موضع الفاء ؛ لأن موضعها يُجزم إذا كانت جواب المجاز اة ، ومن رفعها على أن بعطفها على ما بعد الفاء فهو أجود ، وهي قز أهة " (0) . وكنلك ما أورده من القراعات في كلمة (فأزلهما) من قوله تعالى : مأى

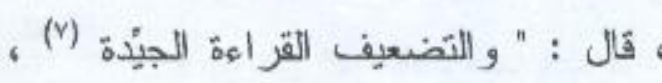

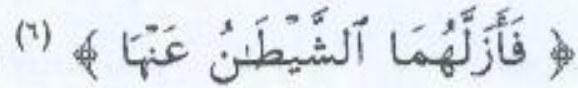
وبها نقر أ.

$$
\begin{aligned}
& \text { نفسه / ن }
\end{aligned}
$$

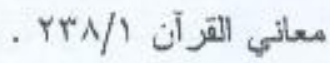

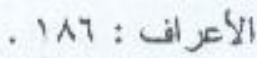

قرأ بالزرفع أبو عمرو ، و وعاصم ، ويعقوب ، وقرَأ بالجزم حمزة ، و الكسائي .

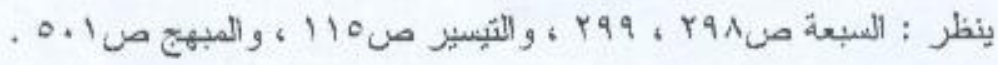

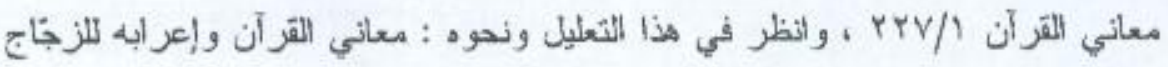
ه

$$
\begin{aligned}
& \text { والبحر \&r/ } \\
& \text { البقرة : r البجر }
\end{aligned}
$$

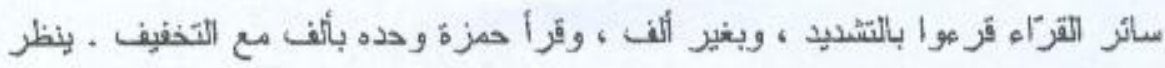

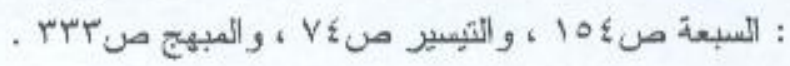




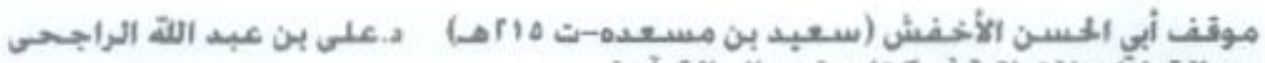

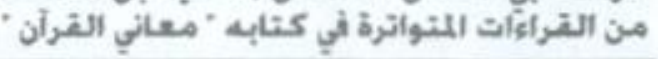

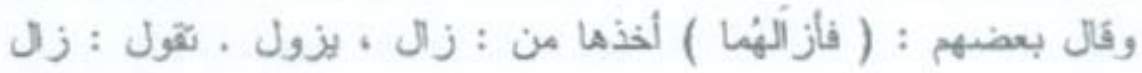

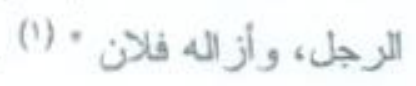

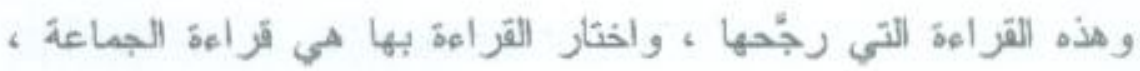

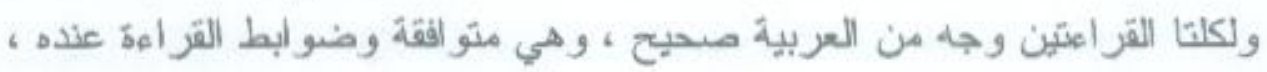

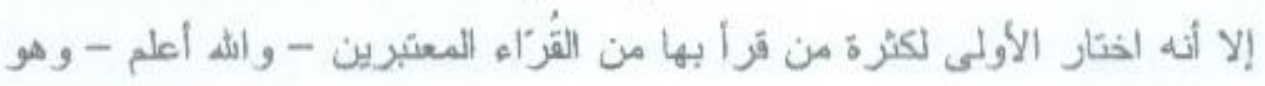

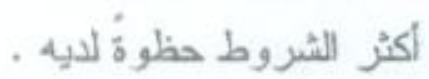

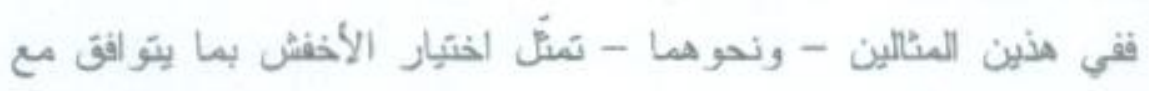

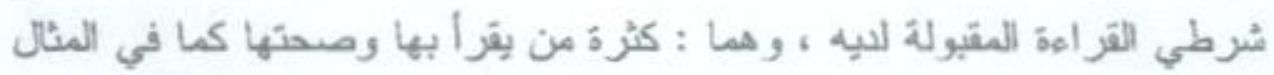

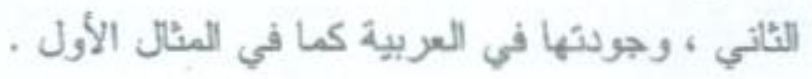

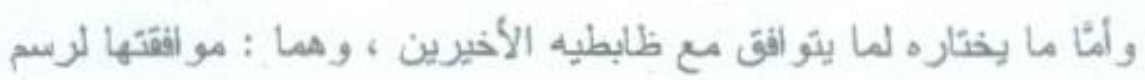

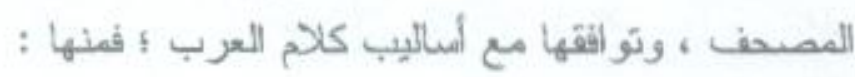

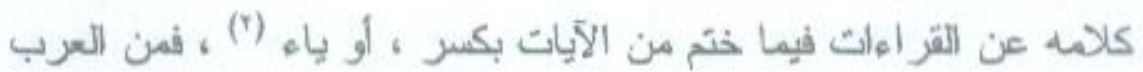

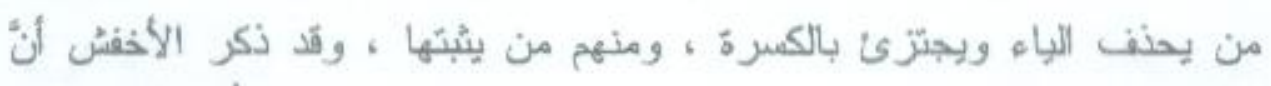

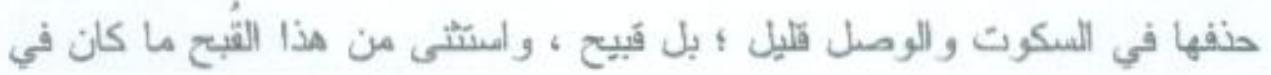

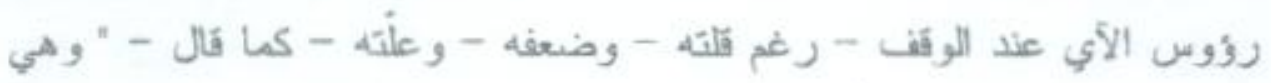

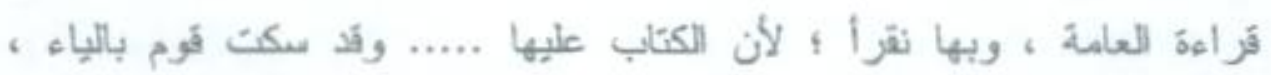

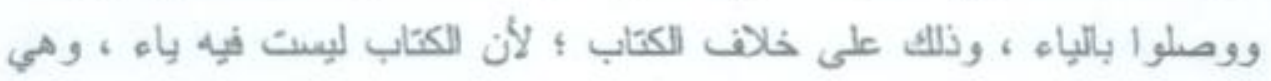

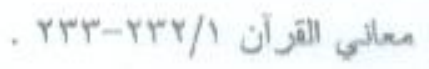

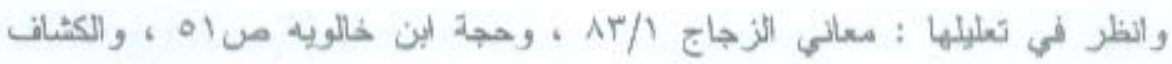

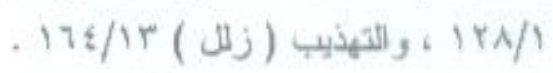

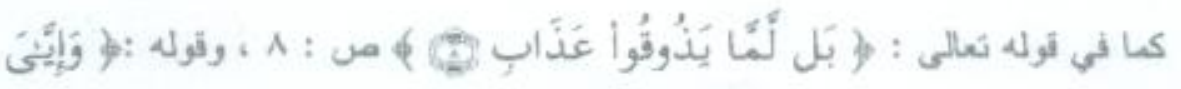

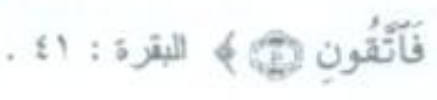




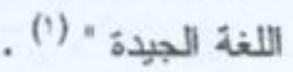

أرأيت كيف الختار اللغة القلية، وجعلها قراعته رغم وصفه الأخرى

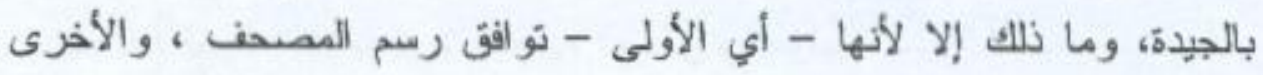

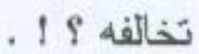

ومنها ما أورده من فر اءعات في كلمة ( درَستت ) من قوله نعالى :

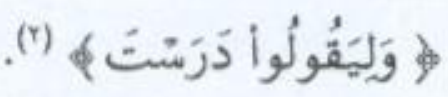

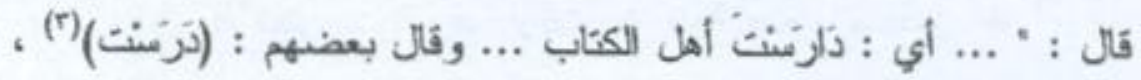

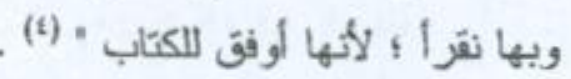

هذا فيما و الفق رمسم المصحف ، وهو كثير (0) ، ، وأمّا ما توافق وأماليب

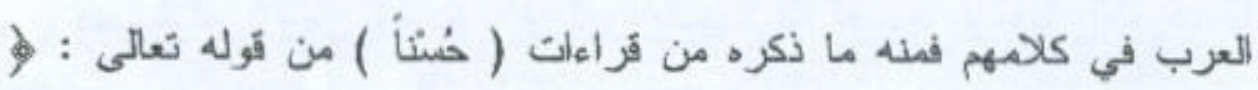

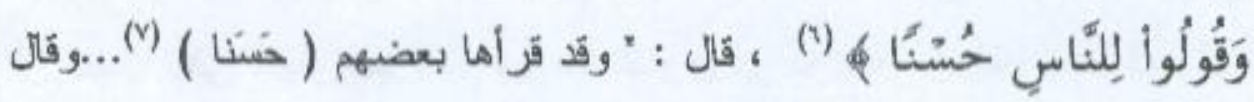

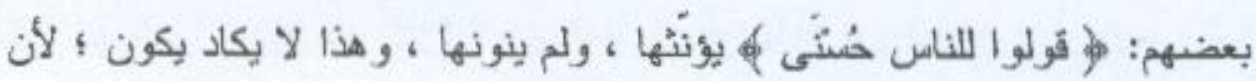

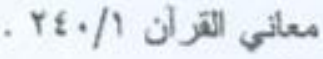

$$
\begin{aligned}
& \text { الأنعام : 1.0 }
\end{aligned}
$$

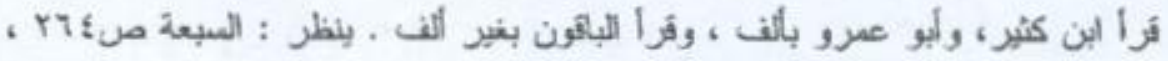

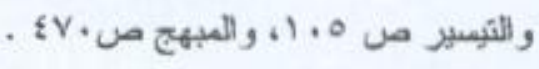

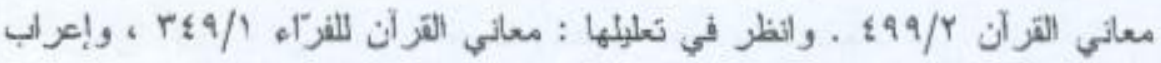

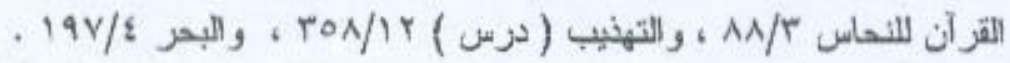

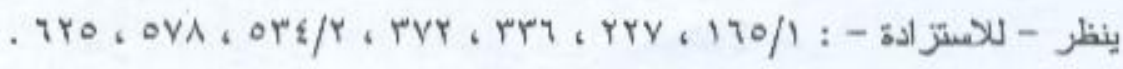

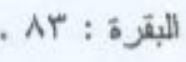

قرا حمزة، والكسائي، ويعقوب بفتح الحاه و الممين، وقرأ الباقون بضم الحاء وسكون

السين .

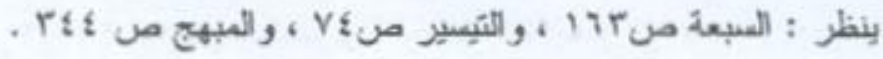




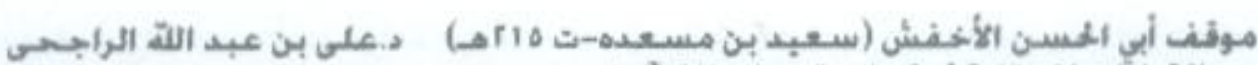

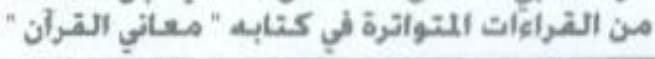

( الحُسنّى ) لا يتكلم بها إلا بالألف واللام ، كما لا يتكلم بتنكير ها إلا بالألف

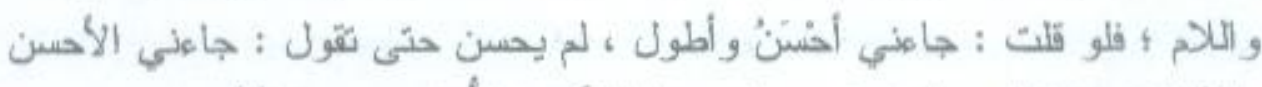

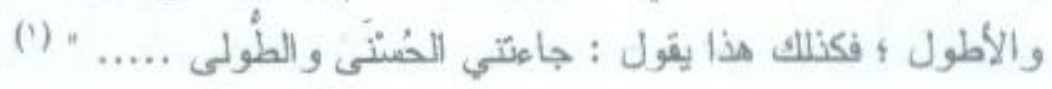

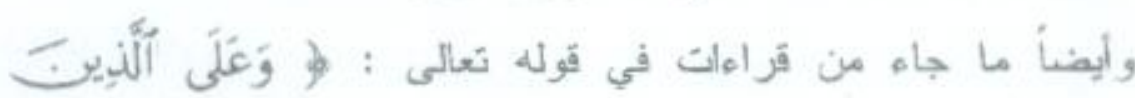

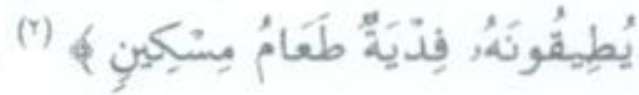

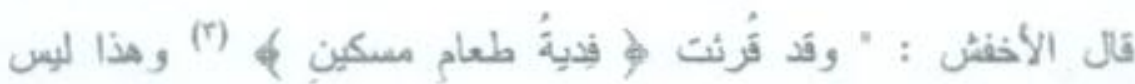

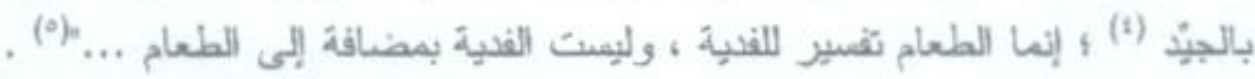

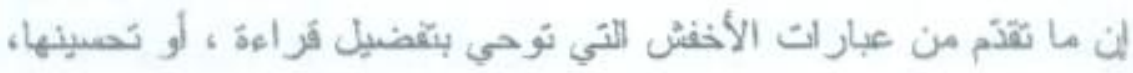

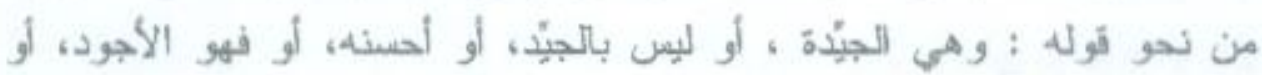

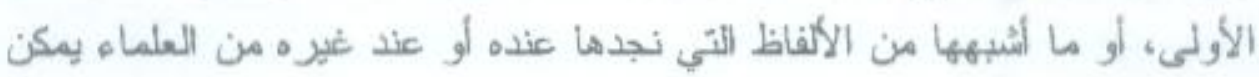

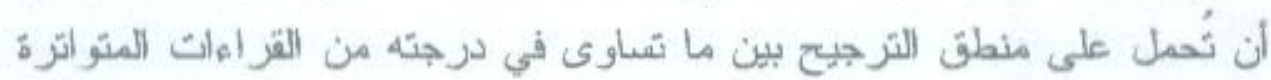

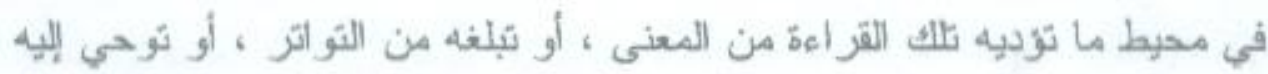

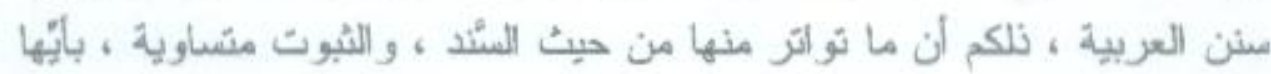

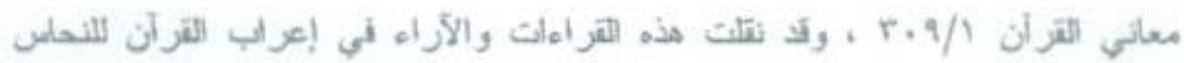

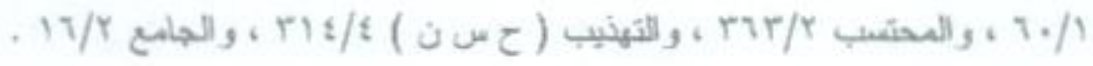

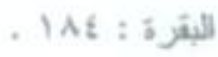

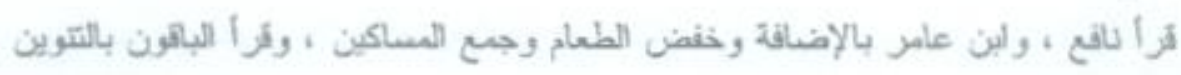

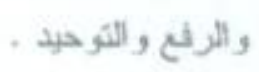

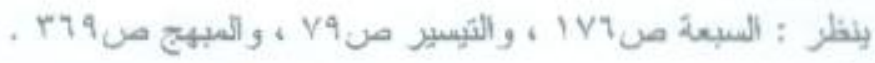

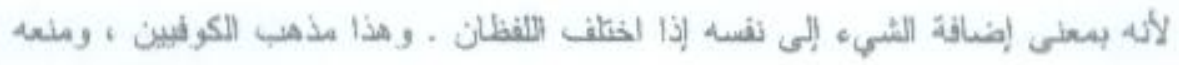

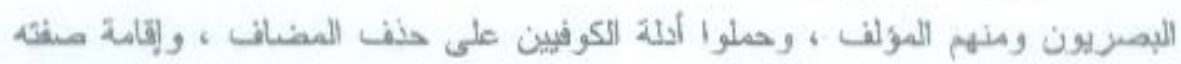

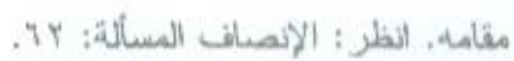

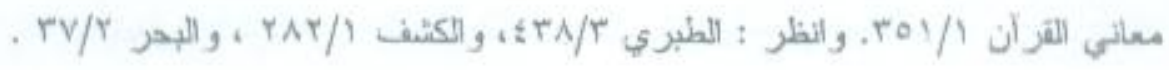




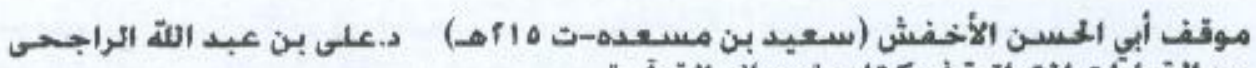

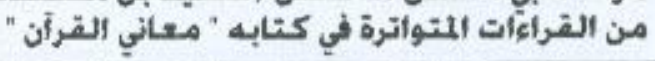

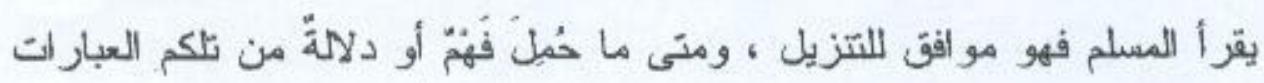
يخرجها عن ذلكم المحيط فهو مردود جملة وتفصيلاً، فالقز اعات مردّها السئند، وليس الاجنهاد، أو القِياس، فهي أصلل ، والتعليل، أو الاحتجاج يخدمها، لا

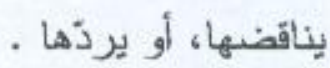

كما أن اجنهاد العالم بافتر اض قر اهذ حسب ما تجيزه أقيسة اللخة عنده ، أو الذوق اللغوي للعالم ، لا يسوّغ أن تُعذ منت هذه الاجنهادات والافتر اضشات

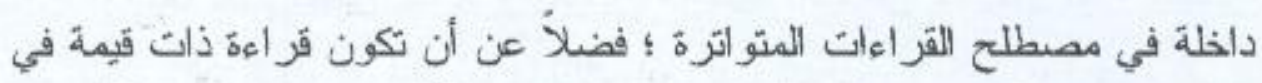
هذا الكيان ؛ لأن القزاعة ليس فيها مجال للقياس ، أو التخمين ؛ بل هي سذة

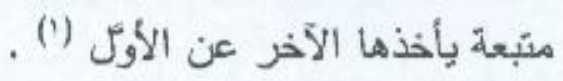

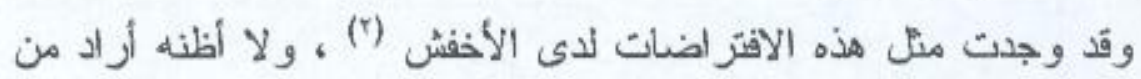

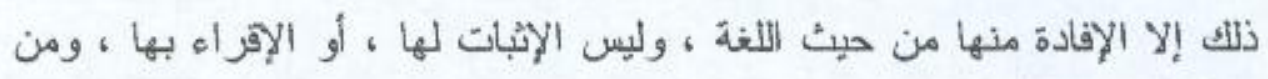

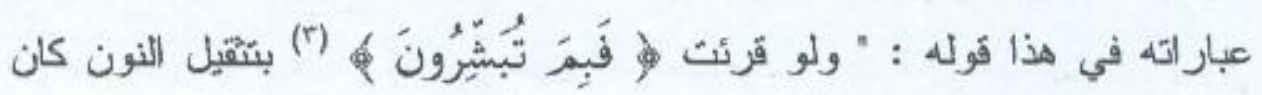

$$
\text { جيدأ ولم أسمعه " (i) }
$$

وقوله : "و هي حسنة ولم أسمعها من العزب " (0)

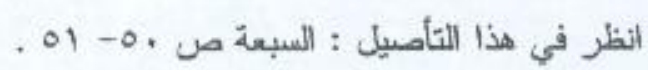

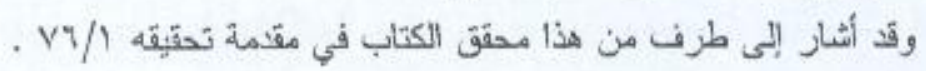

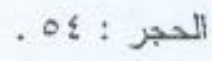

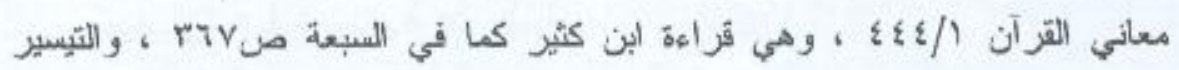

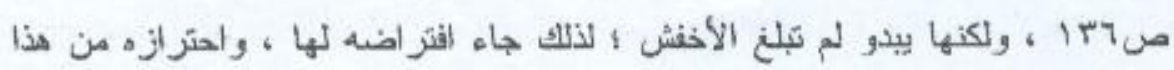

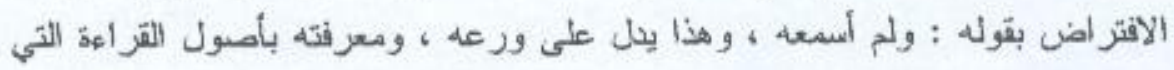

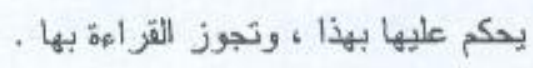

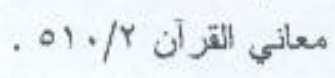




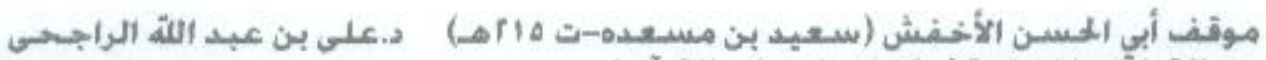

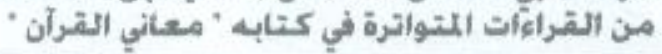

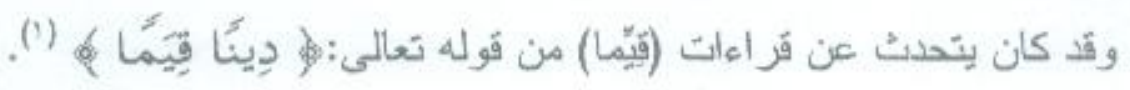

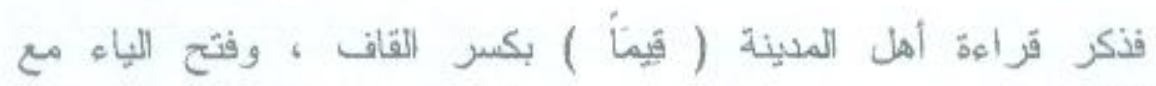
التخفيف(r) وقال عنها : " وهي حسنة ، ولم أسمعها من المربب ، وهي في وهي (r) " معنى المففنز

الموقف الثالث : إنكاره بعض القراعات المنتواترة ، أو تضعيفها . ربما حكمّ بعض النحاة و اللغويين ، ومنهم الاخفش مقاييين اللغنة و النحو على بعض القز اعات ، و أخضعو ها لبتلك القو اعد و القو أنين ، فاجنز عوا ألى شيء

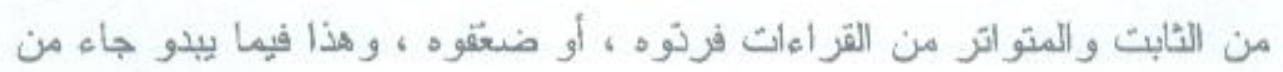

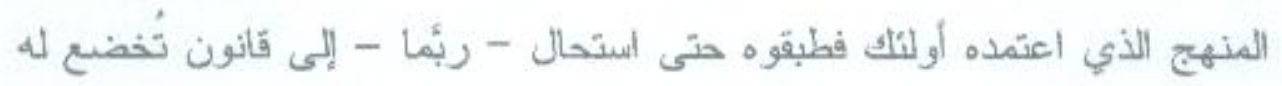
جميع المقاييس (2) ، وليس العكس ، فأدى بهم إلى الوقوى فئى في مزلق كبيز ، وشرك خطير ، ثنج عنه إنزال أرقى نص عربي وهو القرآن الكريم على تلك في

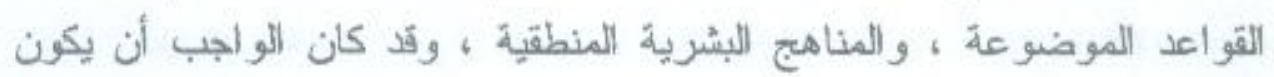
العكس بحيث نصحم قو اعد العربية ، و شو اهدها غير القر آنية وفق ما جاء في كتاب الله وقر اعاته الصحيحة . والنسنعرض بعض هذه المواقف غير الموفقة اللَي جاعت عند الأخفش ؛

الأنعام : 117

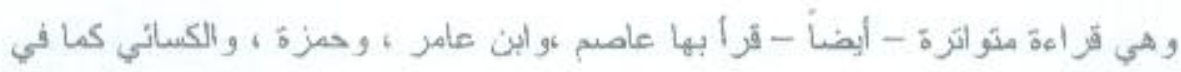

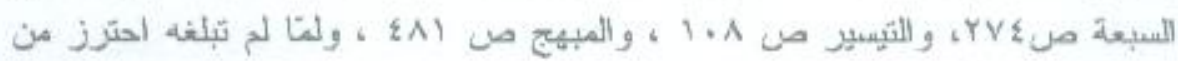

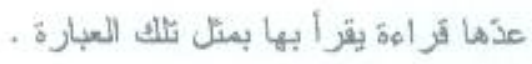

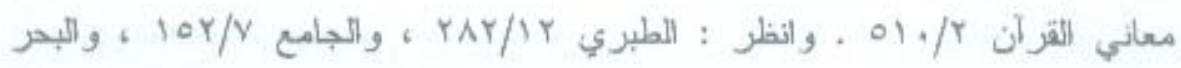

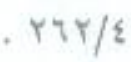

انظل في هذا المنهج : النحويون و القرابات المقرآثية لزهير غازي زاهد - مجلة آدأب

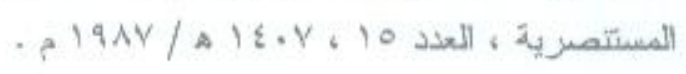




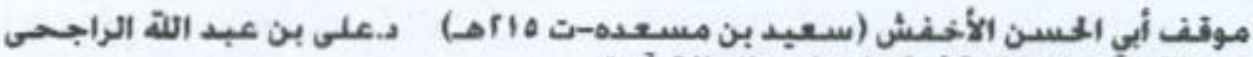

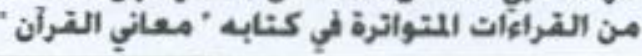

لنبئن خلل هذا المنهج الذي كان ينبغي لمثل الإمام الأخفى أن يربأ بكتابه عن منّله

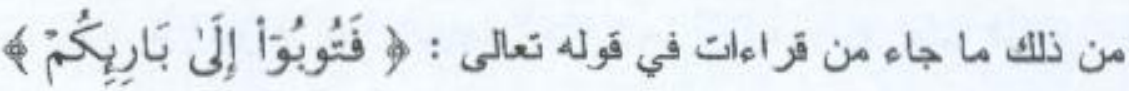

(1)، حيث يقول : " وقد قرأ بعضهم هذه الههزة بالتخفيف ، فجعلها بين الههزة وبين الياء (r) ، وقد زعم قوم أنها تجزم ، ولا أرى نلك إلا غلطاً منهم ، سمعوا اللخفيف فظلنوا أنه مجزوم ، و التخفيف لا يفهم إلا بمشافهة ، ولا بعرف في (r) الكتاب ، و لا بجوز الإسكان

فهذه القز اهة التي غلطهها الأخفش ؛ بل حكم عليها بعدم الجواز هي قر اهذ إمام من أئمة اللغة والقزاعات المعنبرين، إمام العزبية، والثقة، الثُّتب ألبي

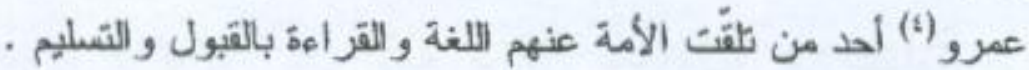
قال ابن الجزري وهو يتزجم لميليويه : " روى القراعة عن أبي عمرو

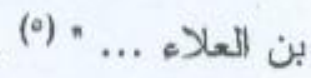

وذذه القز اعة قد طعن فيها كثير من نحاة اللبصرة : كالمبرد ، و الززّجاج ،

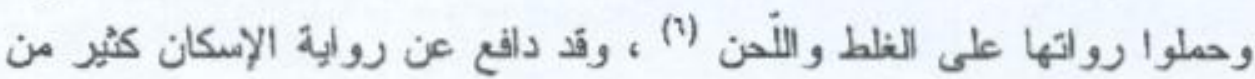

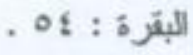

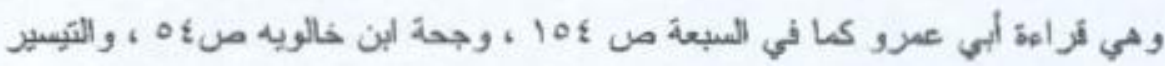

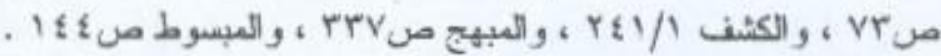

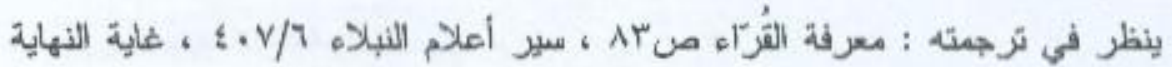

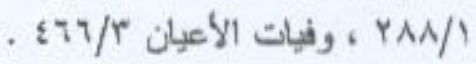

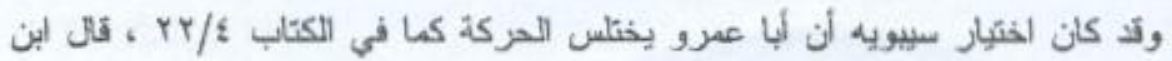

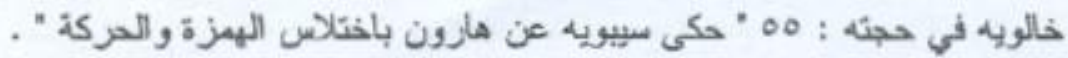

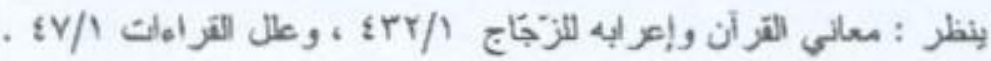


علماء العزبية كابن الجزري (1) ، و أبي حيُّن (r) على أنه إجراء للمنفصل من

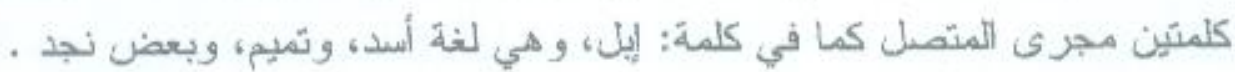

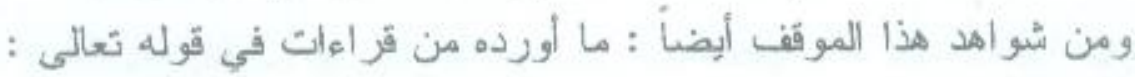

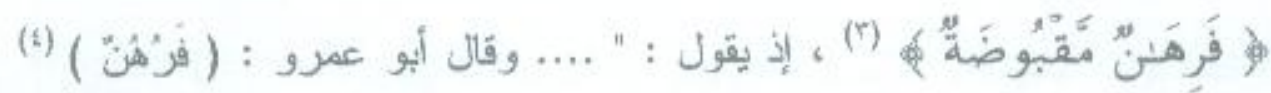

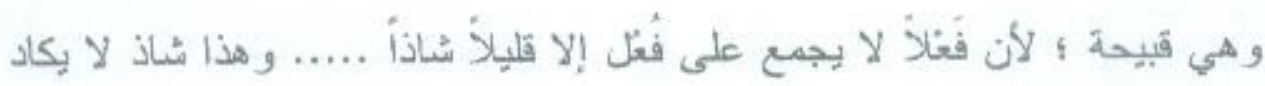

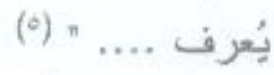

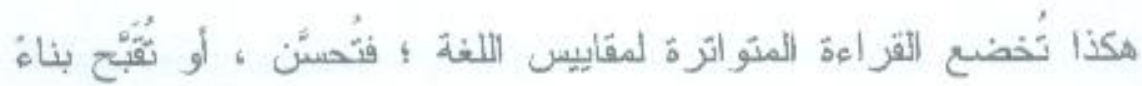

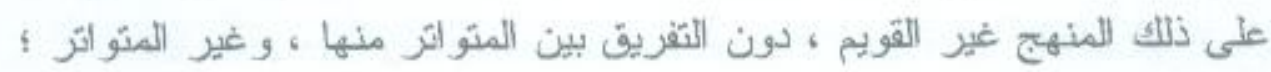
بله المسنعل في النظام اللغوي المنكامل من مجموع لهجاته ولغاته .

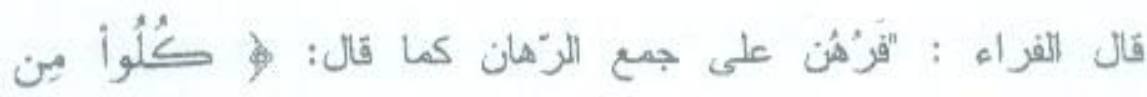

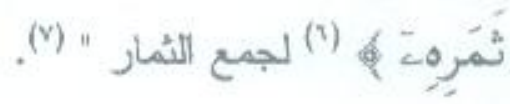
وروي عن يونس أنه قال : اللرهنه و الرهان وراحدّ عربيتان ، و المرهن في

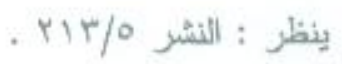

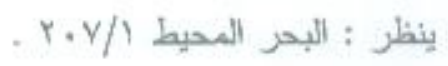

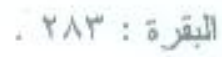

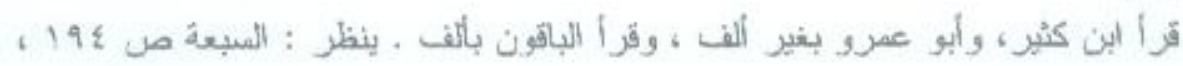

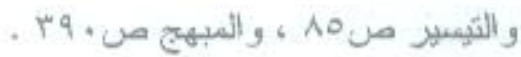

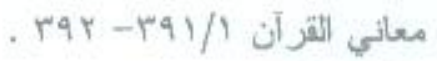

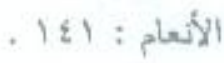

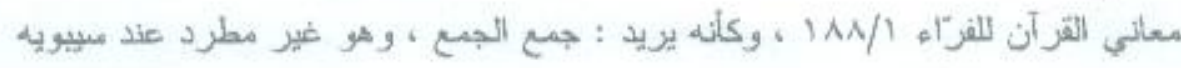

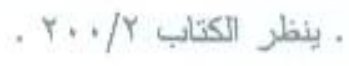




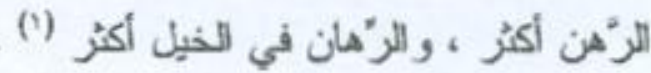
وقال أبو منمور الأزهري : " من قرأ (فرُشن ) أراد أن يفصل بين

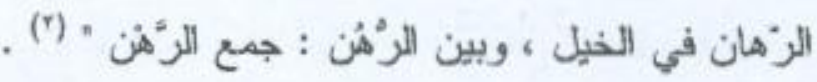
أفلا تسع هذه المعاني دن العربية الفصحى هذه القراهة ؛ لاسيما وهي المثواتزة ؛ بلل رذها ، أو تقبيحها ،و قد جاء ذلك عن الأثمة المعتبرين من المدرسئن البصرية و الكوفية ، وقرأ بها الأئمة النقات كابي عمرو ، واين كثير ؟ ! إنها المقاييس المقيتة التي رسموها من واثع نظام لغويخ محدود فيه القوي من حبث الفصاحة والضعيف ، ثُ جاءوا بها لنطبيقها على أرقى نص لغوي وأفصحه ألا وهو القرآن الكريم الأي ربما اختلف بعض نظمه هع بعض بلى المقاييس و القو انين ، فصار العلماء في هذا بين أمرين أحلاهما مر" ، فوقعوا فيما وقَّوا فيه من هذا الخلل المنهجي من غير عمد . ومن أمثلة ذلك الموقف غير الموفق - كذلك - ما حكم به على بعض

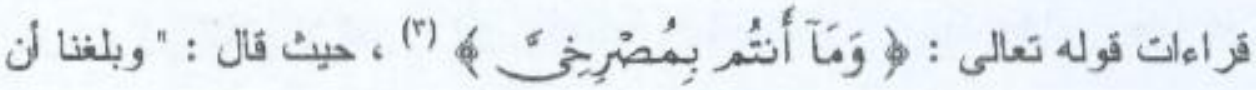
الأعمش قال ( بمُفزخئ) )(t) فكسر وهذه لحنّ لم نسمع بها من أحد من العرب

ينظر : التهذيب ( رهن ) rVo/r ، والبحر المحيط roo/r ، واللعبان ، والتاج (j)

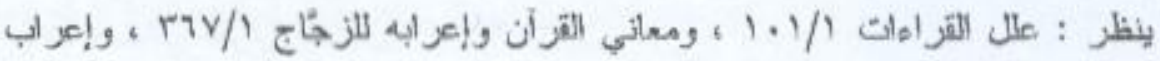

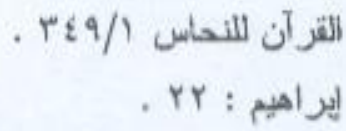

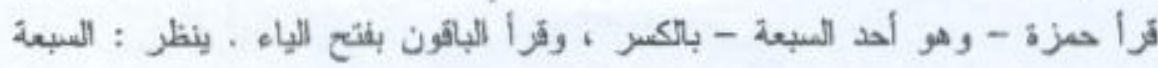

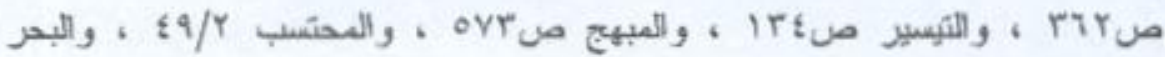




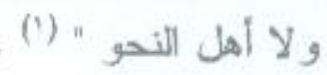

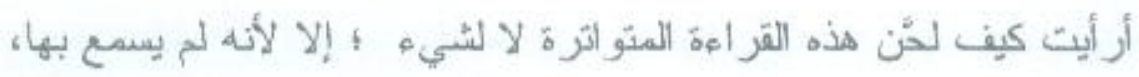

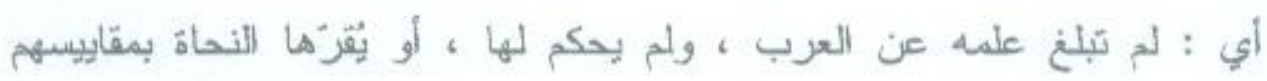

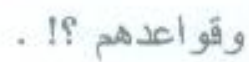

وقد تبع معظم النحاة واللغويبن الأخفش في ثلحين ، أو تضعيف هذه

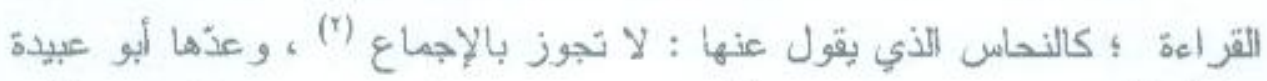

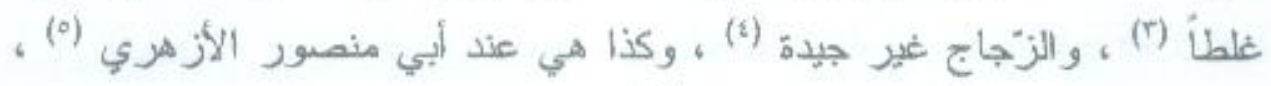
وحكم عليها الفرّاء بأنها وجه ضنعين

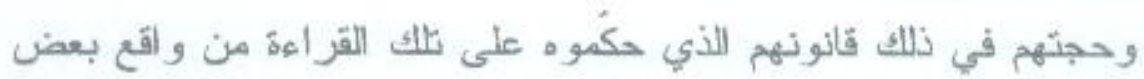

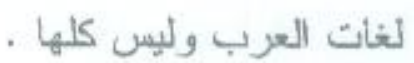

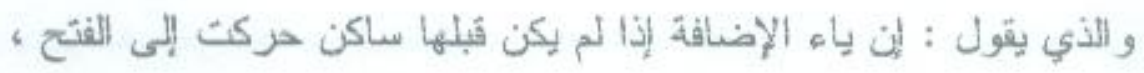
ويجوز - عندهم - إبكان الياء لنقل التي قبلها كسرة ، فإذا كان قبلها ساكن

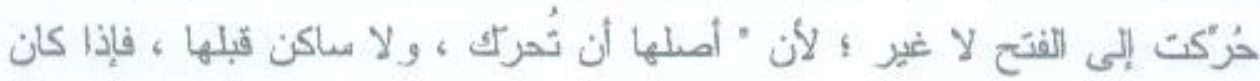

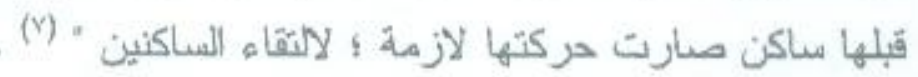

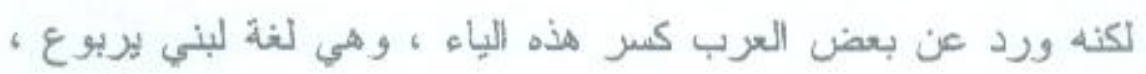
و الكسر على أصل الثقاء الساكنين ، وسوّغ الكسر مع نقله على اللياء ، أن اللياء

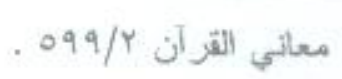

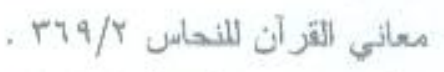

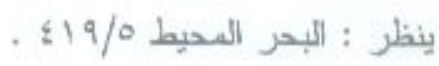

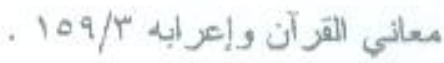

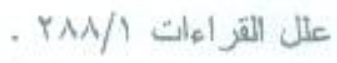

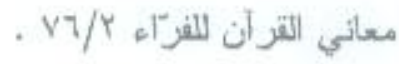

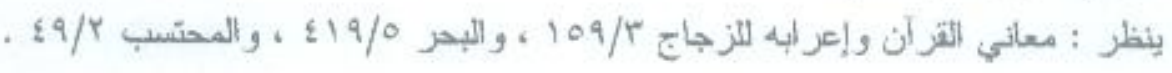




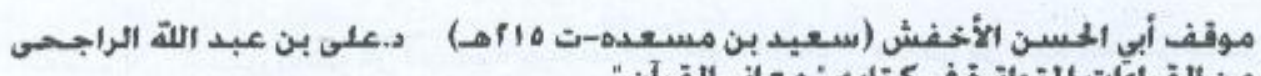

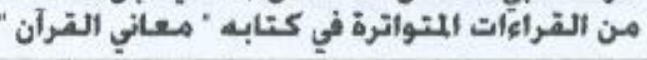

إذا سكن ما قبلها كانت بمنزلة الحرف الصحبح (") لمقد أجاز هذه اللغة جملة

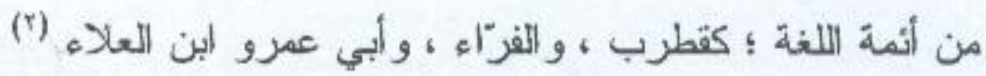

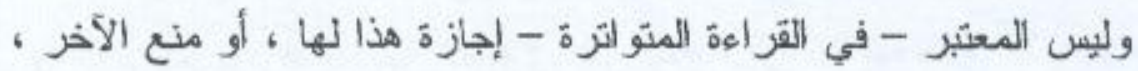

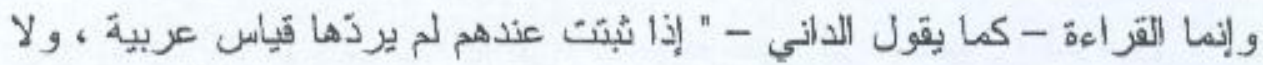

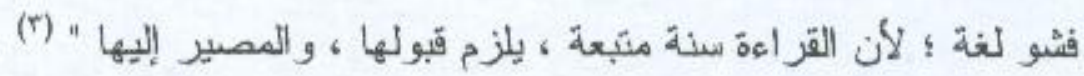

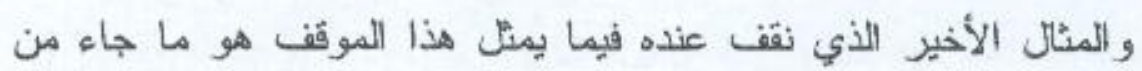

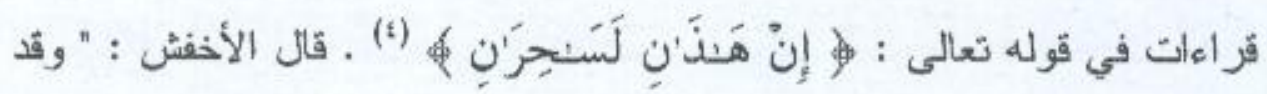

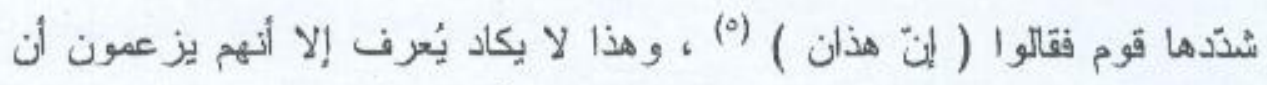

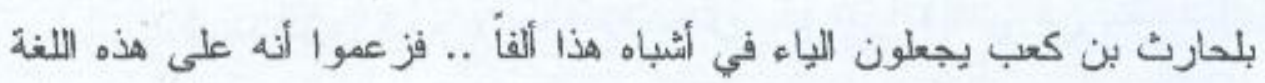
بالتبقيل تقر أ .

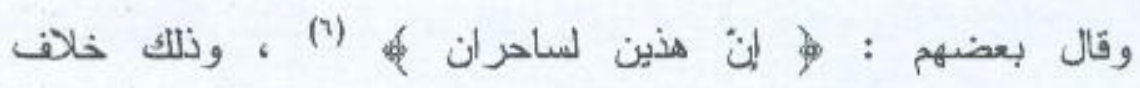

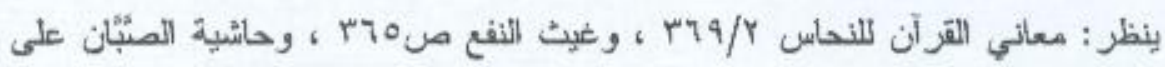

$$
\text { الأشموني YAN/Y }
$$

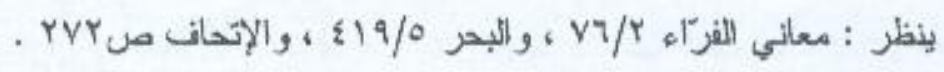

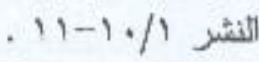

طג : זו .

وهي متوائزة - سبعيتة - قرأ بها نافع ، وابن عامر ، وحمزة ، و الكسائي ، وعاصم في

$$
\text { رواية. }
$$

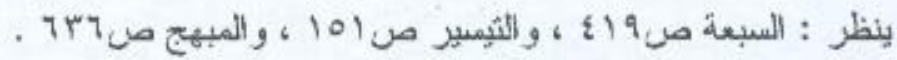

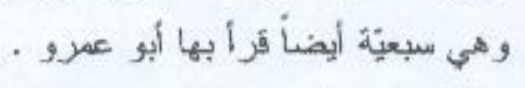

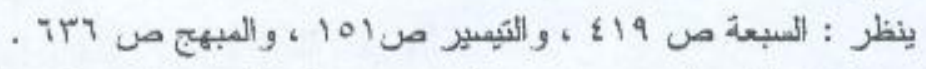

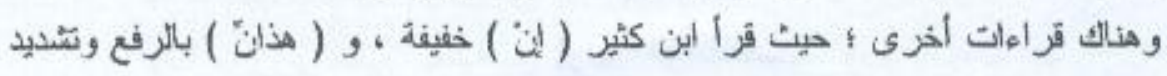

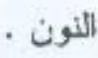
وقرا حفص ( إن هذان ) بالتخفيف و الثرفع ـ ينظر في المصادر ما سبق . 
(1)" (لكتاب (1)

و القز اهذ الأولى التي هي بالتشليل و الرفع التي حكم عليها الأخفش بأنها

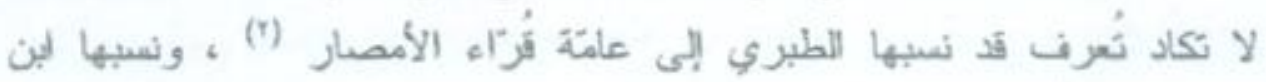

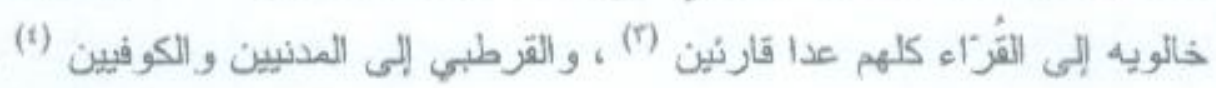

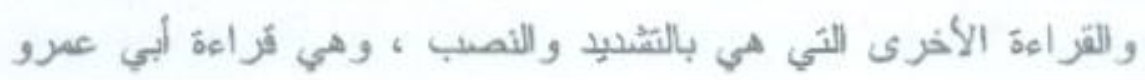

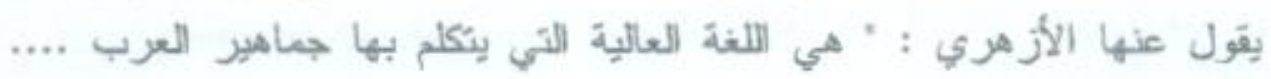

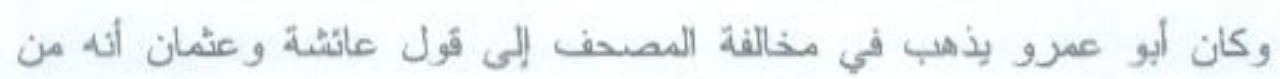

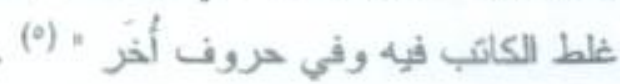

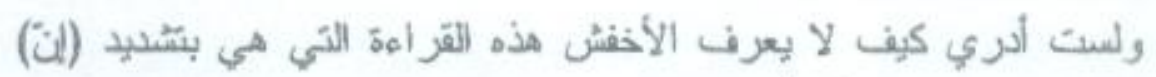

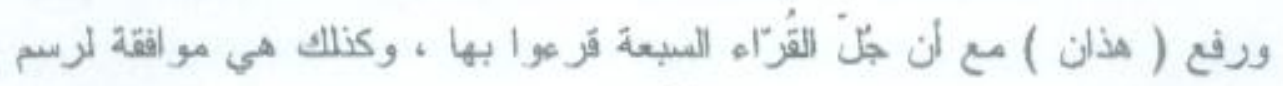

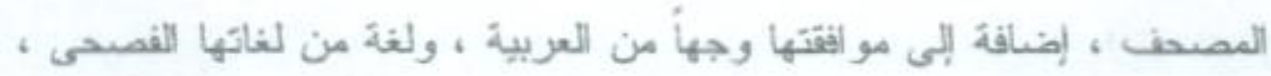

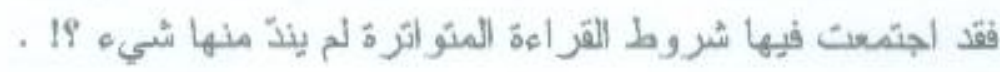

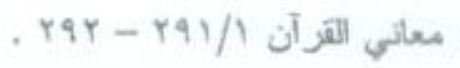

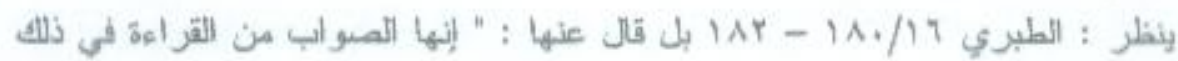

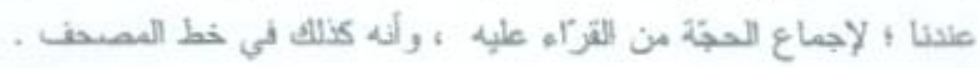

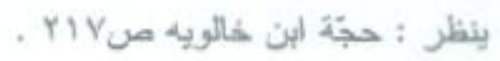

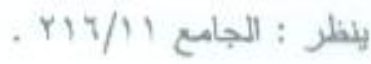

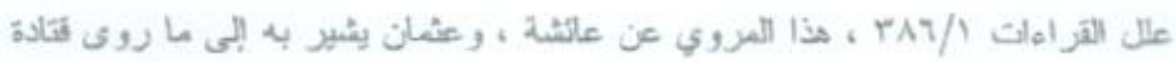

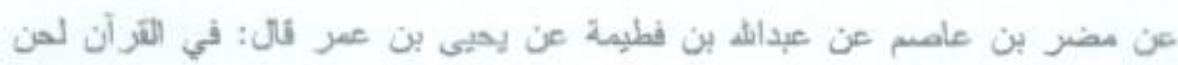

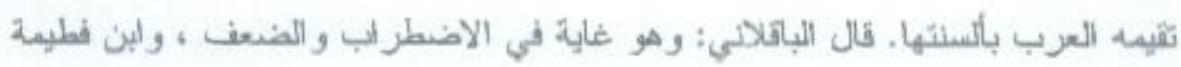

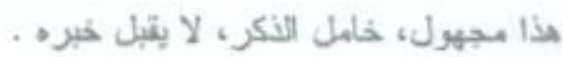

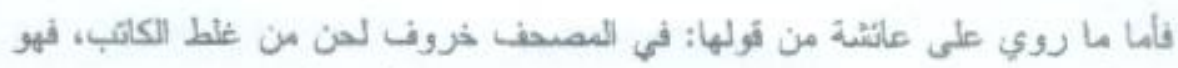

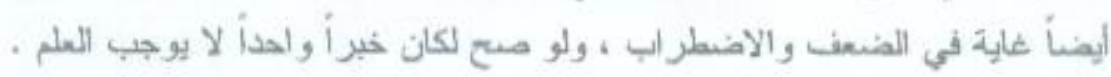

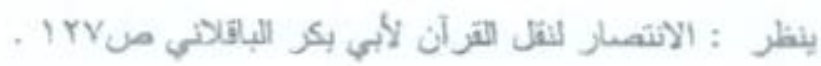




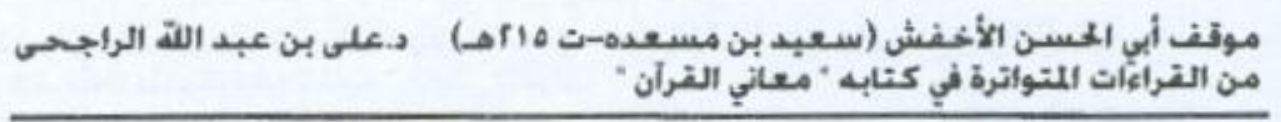

ثُ الن القراعة الأخرى الني قال عنها : هي خلاف الكتاب ، هي قراهة

أبي عمرو الإمام الثقة الثبت في اللغة والقزاعة ، وكذلك احنمال الرسم لها ، وليس خلافه ؛ نللك أن لفظة ( هذان ) وردت في بعض المصاحف العثمانية مرسومة على هيئة ( هذن ) (") من غير ألف ، وهذه الصورة من الترسم حمالة لقراهات عدة ، منها القز اهذ بالياه فيها ، وفي غيرها من بعض ألفاظ القرآن

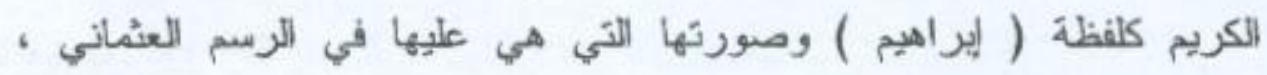
و القز اعات الواردة فيها ؛ فكما أن ( هنن ) تقر أ بالألف ، وهي على هذه الصورة ، فكذلاك إمكانية قر اعتها بالياء ، وكل نلك بيتو افق مع رسم المصحف.

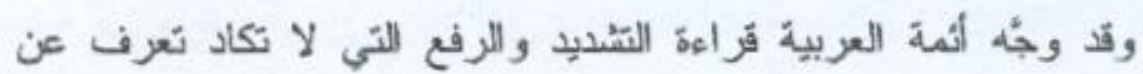
الأخفش بتوجيهات كلها فوبلة وحجة منها :

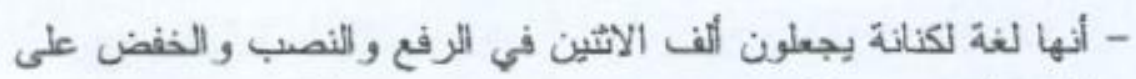

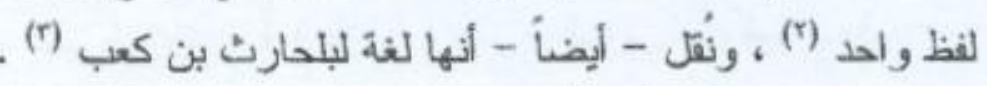
- وقالوا -أيضنأ- هونا (هاء) مضمرة المعنى: أي : إنها هذان

(i) لساحران - وقيل : إنها أي : ( لنة ) بمعنى (نعم ) هذان لساحرلن . والن اللحم وقعت موقعها ، والمعنى : نعم هذان لهما ساحران ، واستحسن الزّجّاج هذا

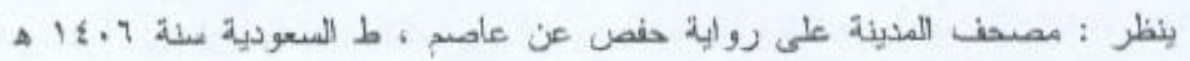

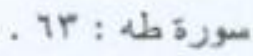

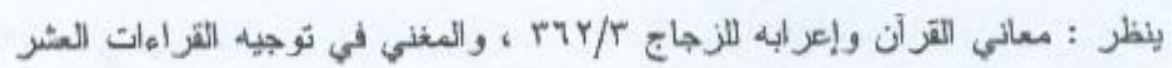

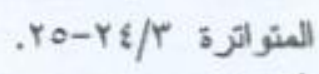

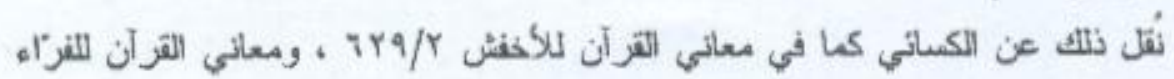

$$
\text { . } \mid A \varepsilon / r
$$

$$
\text { وهو قول للزجاج - أيضاً - في معائيه ب/r r r م . }
$$




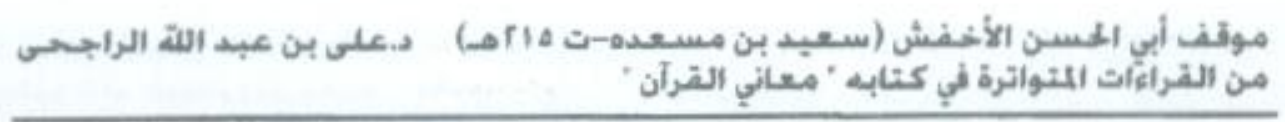

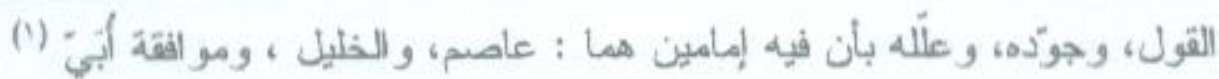

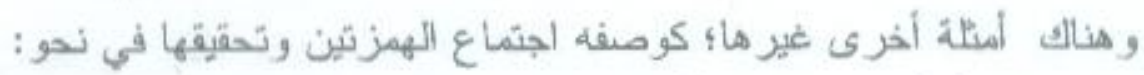

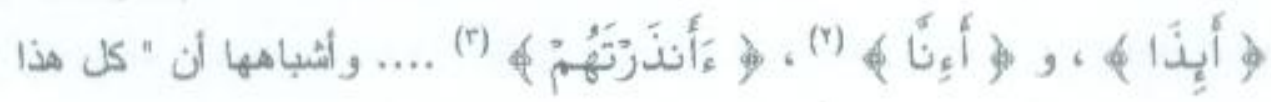

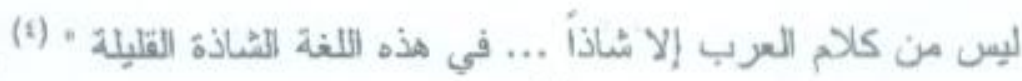

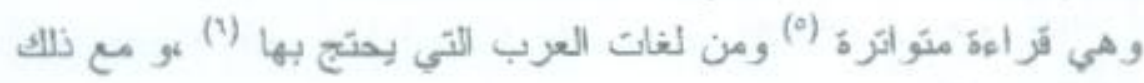

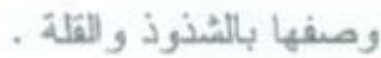

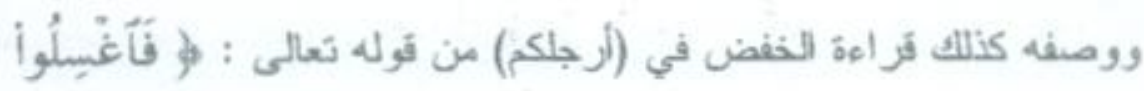

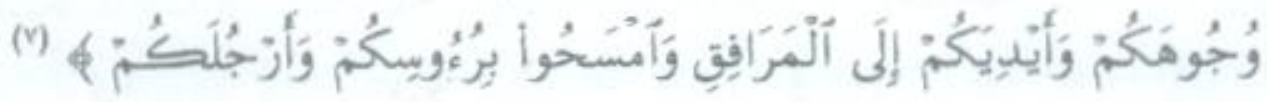

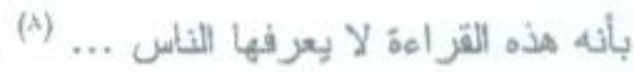

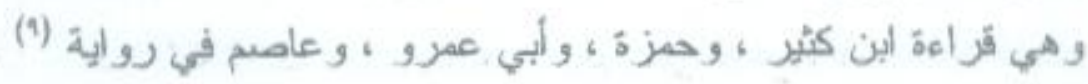

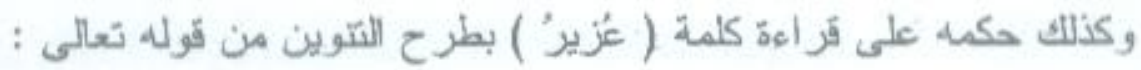

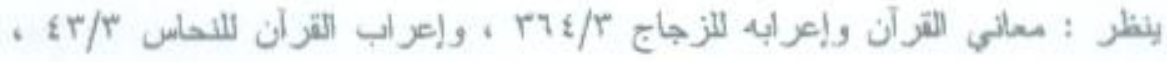

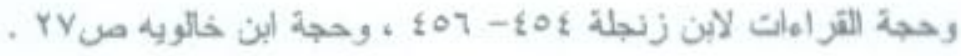

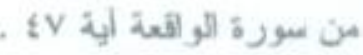

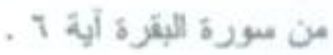

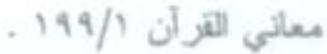

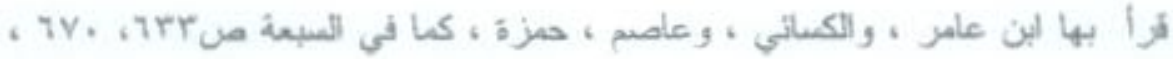

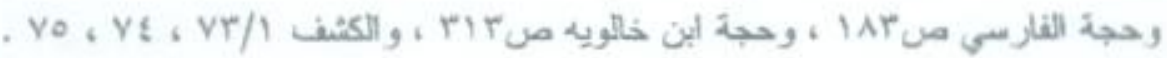

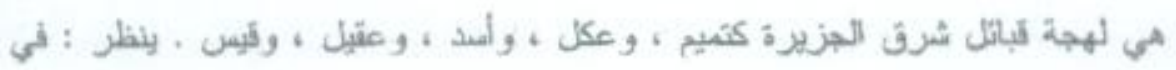

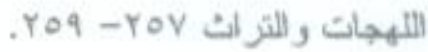

$$
\begin{aligned}
& \text { المائدة: : المجات } 1 .
\end{aligned}
$$

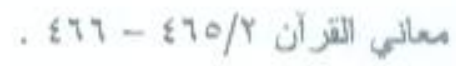

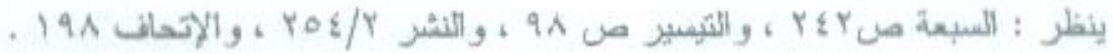




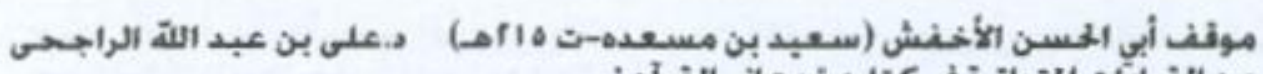

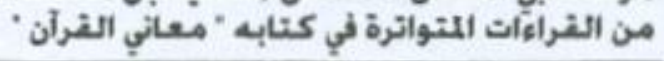

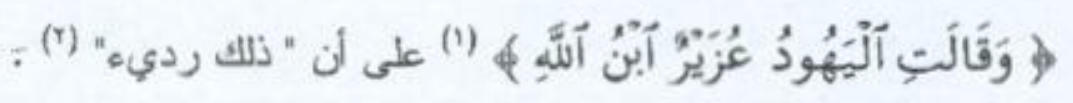

وهذه القراعة التي حكم علدها بأنها رديئة هي قر اهة سبعية متو اتزة قرأ

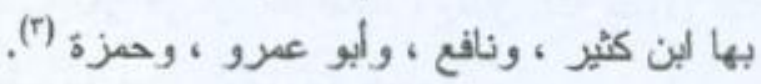

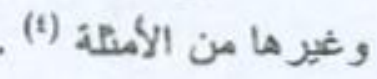

بقي أن نشير البى أن ما أورد الأخفق وغيره من علماء اللغة والنحو هذه

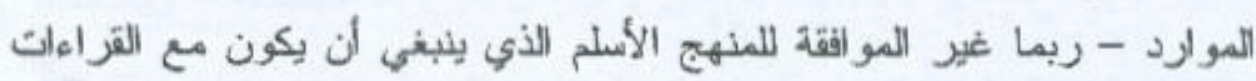
المتو اتزة -هو - كما نحسب ونظن - اجتهادهم في تطبيق قو انين اللغة ومقاييسها التي سبق الحمبث عنها (م) على هذا النوع من المنقول والمروي بأعلى درجات الزروالية والثبوت ، واليز الهم ذلك منزلة النصوص الأخرى الألَ في الصحة والفصاحة ؛ كالثعر ، و اللثر من موروث العرب الذي فيه العالي ، و الأعلى ،و الفصيح ، و الأفصح ، وربما الضعيف ، و القليل ، و اللادر ، و اللشاذ ، والمتزوك ، و غير العزبي

وممًا يُتمُش به العذر لعلماه القرنين الأول والثاني ومنهم الأخفش الذين

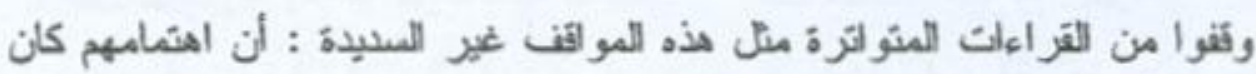

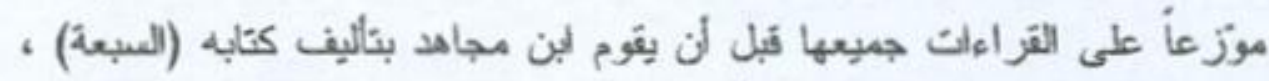
ولم يكن إحلامها مكانة خاصة أمرأ موجودأ في ذهن أولثك العلماء في هذه الفترة الزمنية ؛ لكثرة القزراءات الصحيحة ، والسبع لا ريب هنها ، ولكنها لليست

$$
\begin{aligned}
& \text { التوبة : .r. }
\end{aligned}
$$

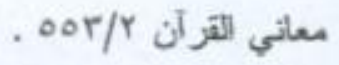

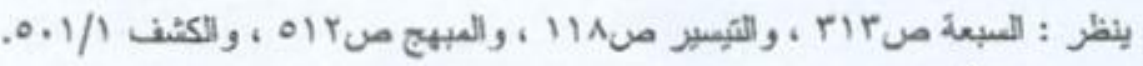

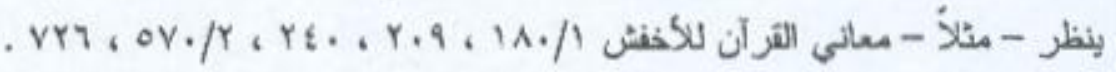

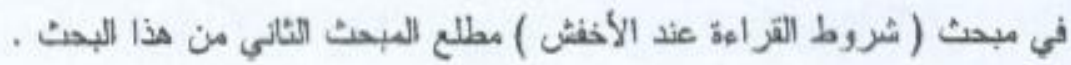




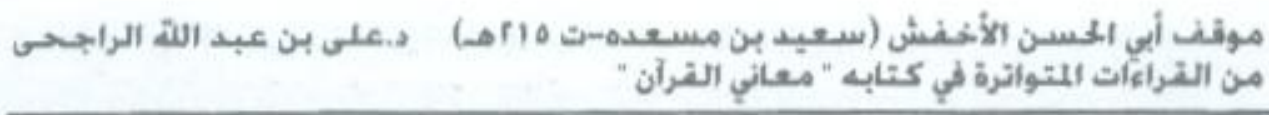
الوحيدة في الصاحة .

وحين ذاع كتاب البن مجاهد في الناس اتجهت الأنظار إليه ، ولقي

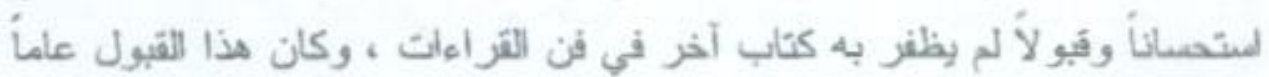

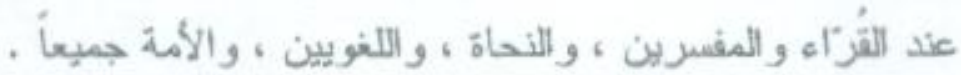

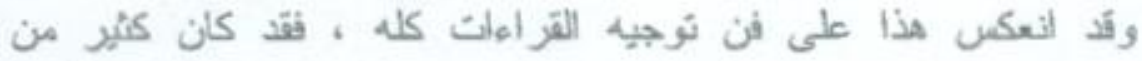

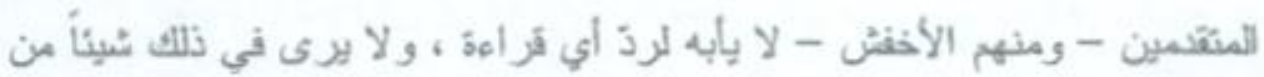
المرع + ولكن الأمر قد تغير بعد هذا تجاه القراهات السبع خاصلة من حيث

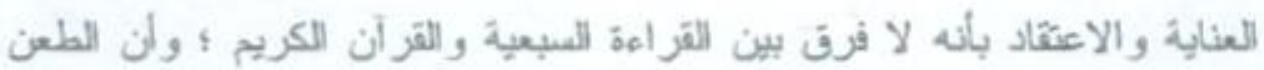

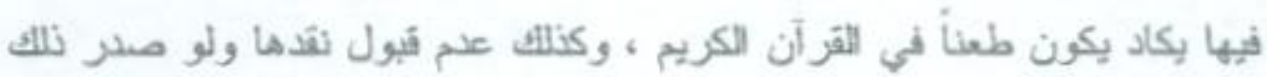

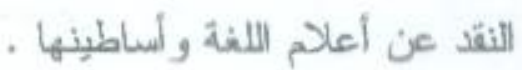

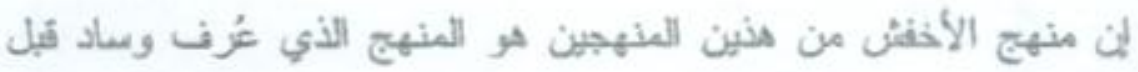

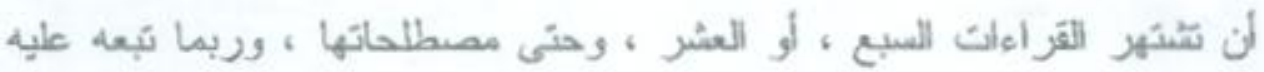
منأخرون حتى بعد الثنهارها ، و عليه فابنه بسهل علينا تقسير ذلك الصوقف منه ومعن عاصر ه، وجعله في نصابه الحقيقي (') وتحت مجهر ميز ان العدل .

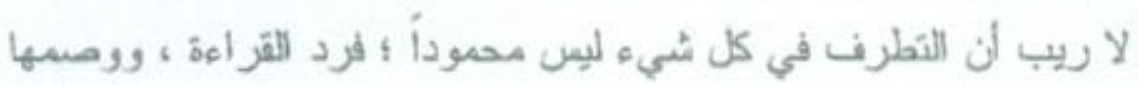

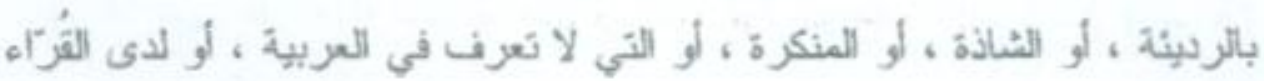

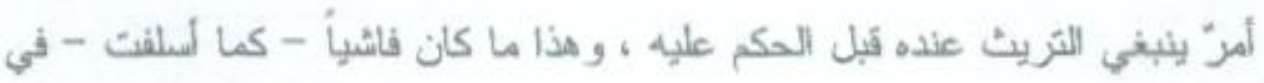

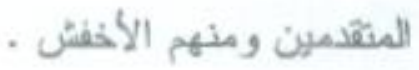

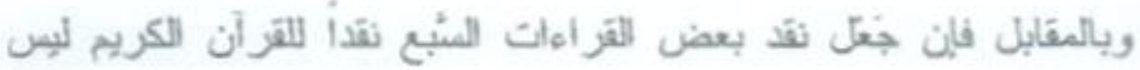

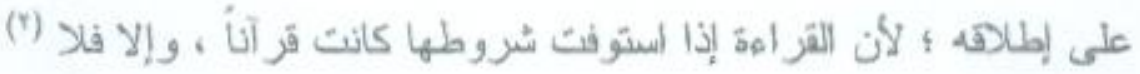
يقول البن الجزري : "ومَد شُرط بعض المتاخرين اللتواتر في هذا الركن،

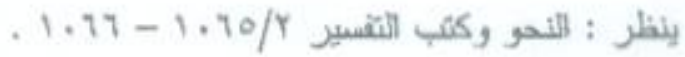

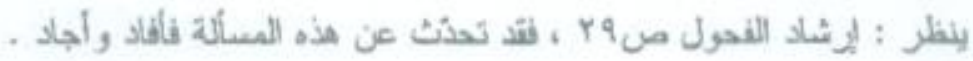




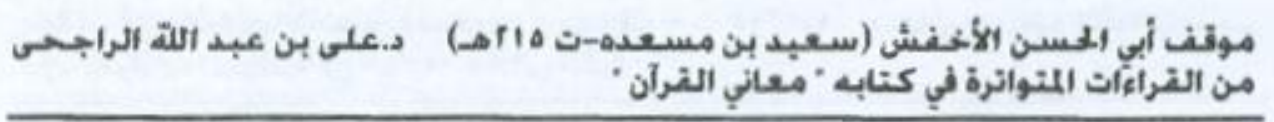

ولم يكتف فيه بصدة السند ، وزعم أن القرآن لا يشبث إلا بالتو اتز ، وأن ما جاء

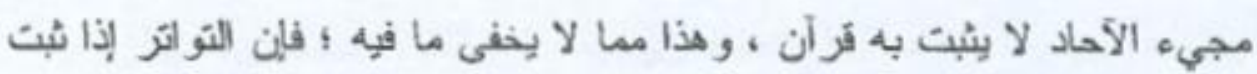

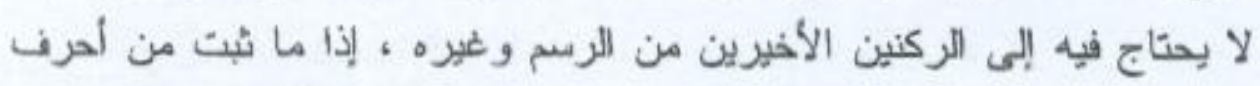

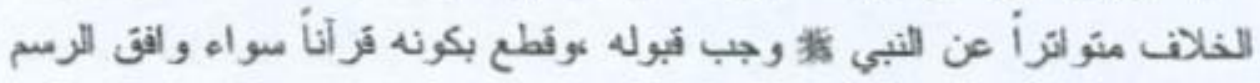

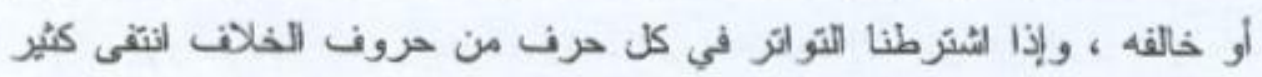

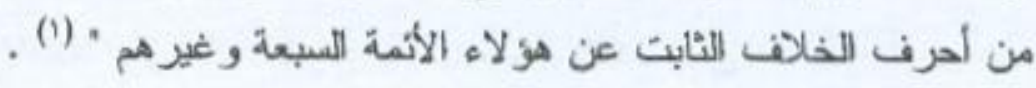




\section{الخاتسمــــة}

القد كان كتاب الأخفش ( سعيد بن مسعدة ) " معاني القرآن " مصدرأ

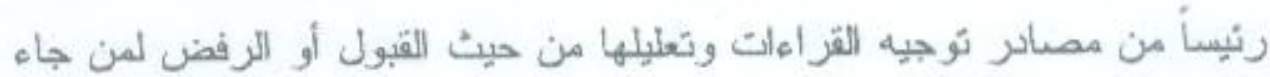

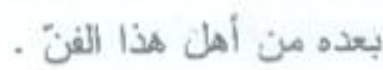

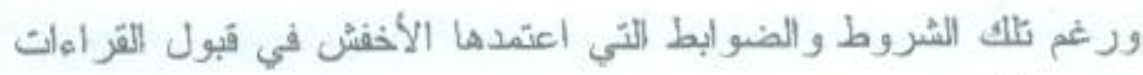

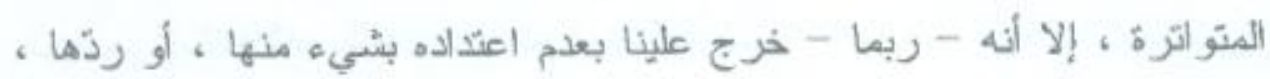

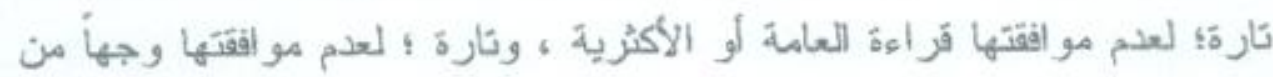

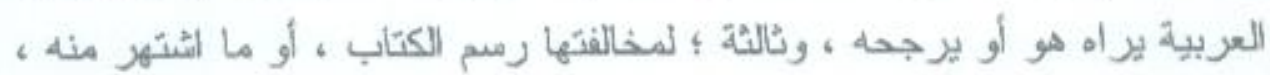

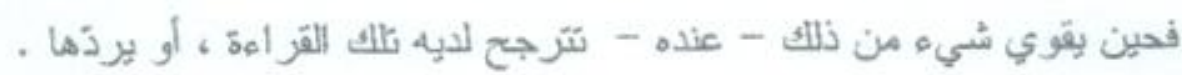

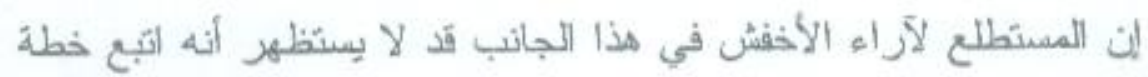

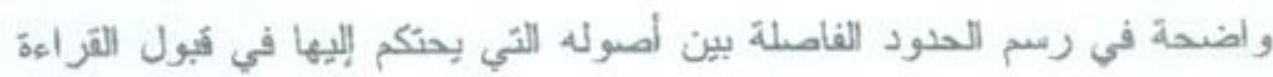

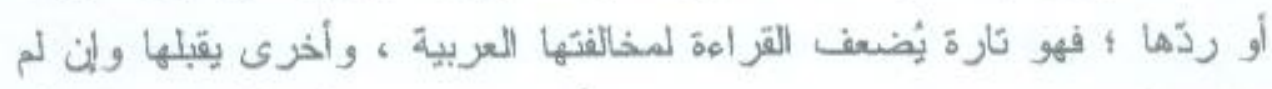

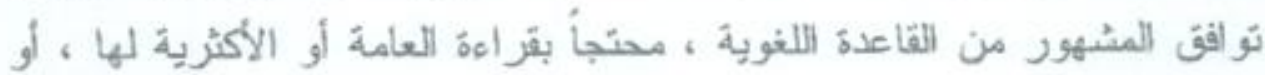

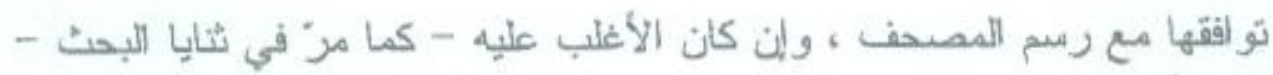

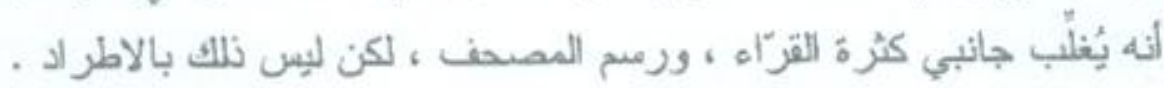

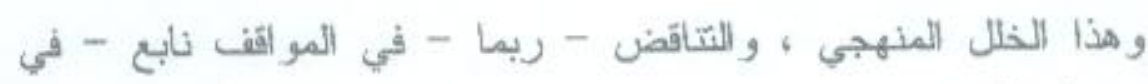

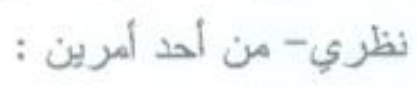

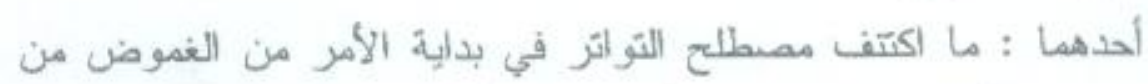

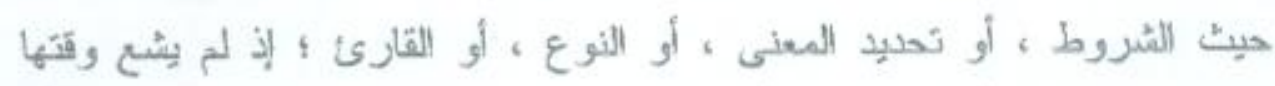

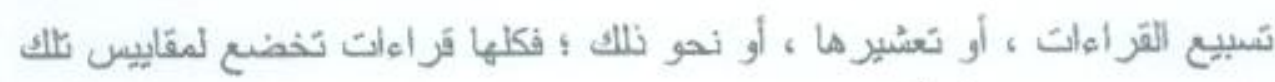

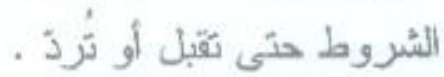

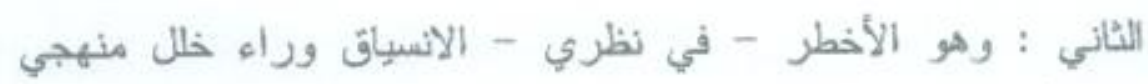

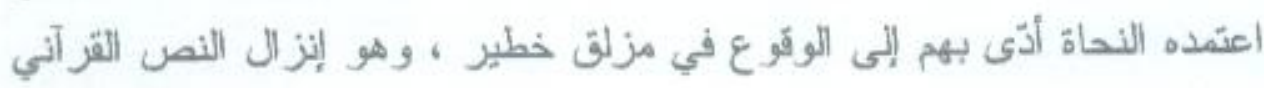




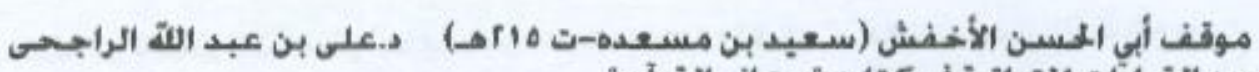

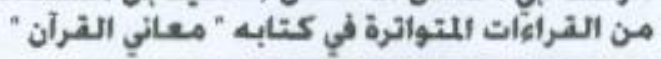

الكريم الأي هو أعلى درجات الفصيح ، قد ملم من التحريف واللصحيف ويقاس عليه قر اءاته المتؤ اتزرة ، أنزلوه مثزلة النظام اللغوي العام في تقعيداتهم ، ومقاييسه - ربما - العقلية ، ومناهجهم المنطقية ؛ فثرى أحدهم قد يستشه

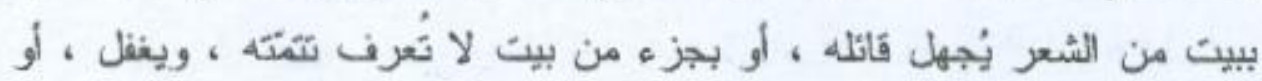

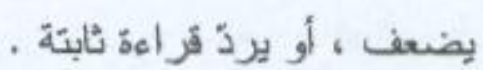
وبالجملة فإن مذهب الأخفش وموقفه تجاه القراءات المتواترة كان منبايناً، يؤدي بالقاريء إلى الحيرة و اللدهة ؛ فهو تارة ينكر ؛ بل بشدد النكير

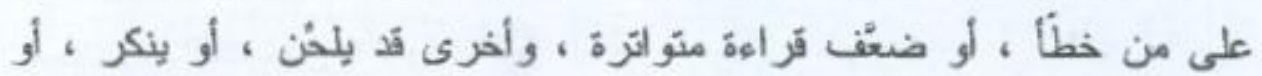

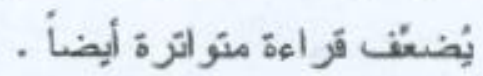

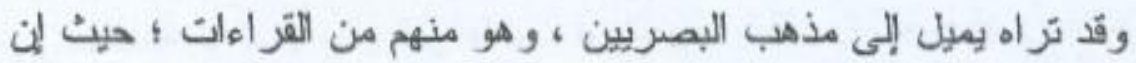

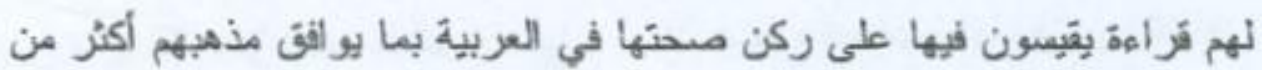
قياسه فيه على الركنين الآخرين ، وهم : مو اقفتها لمرسم المصحف ، وصحة سندها

وفي مواضع أخرى يذاقض هذا المذهب ؛ فيقدم القر اعة المطابقة لرعم المصحف ، أو اللي صع سندها وكثر قراؤها ، وإن كانت على غير المشهور من العزبية في مذهب البصريبن ، ممًا بيدل على أنه ربما لجنه بآراه تخالف آر اء مدرسته الني هو منها .

إلا أنه - في الغالب - يطغى علبه المنهج اللغوي في قُبول القراهذ أو أو رذها ، وليس المثهج المقذّم لدى القُرّاء ، والذي يقول عنه أبو عمرو الداني : " وأثمة القراهة لا تعمل في شيء من حروف القرآن على الأفشى في اللغة والأفيس في العربية ؛ بل على الأثبت في الأثر ، والأصح في النقل . والرواية إذا ثبتت عندهم لم يردها قباس عربية ، ولا ففوز لفة ؛ لأن 


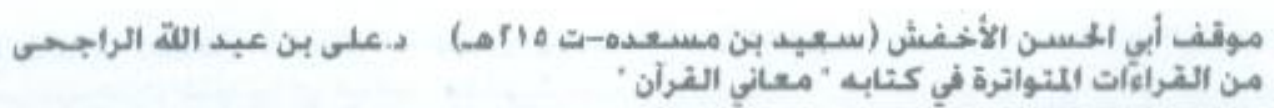

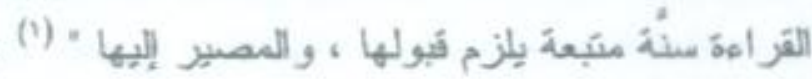

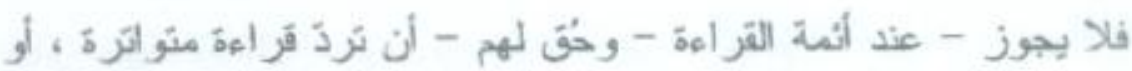
توصف بما لا يتثامسب مع قدر ها ، أو فدر رواتها .

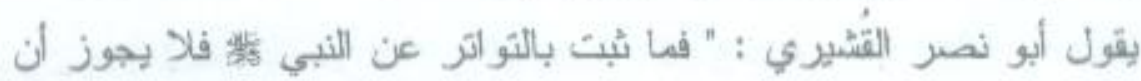

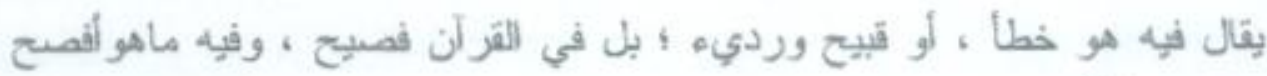
(') "... م

ومهما يكن من خلاف بين مواقف أهل اللغة وأرباب القراءات ، أو من

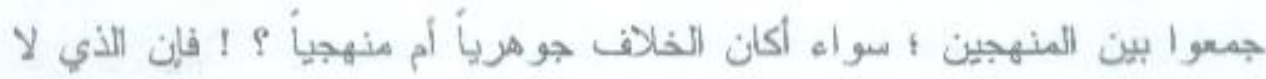
يمكن فبوله بحال من الأحوال أن ينغيد أحد من ألثك - خاصة اللغويين منهب -

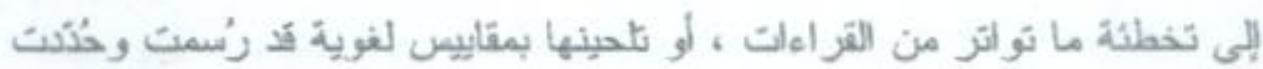

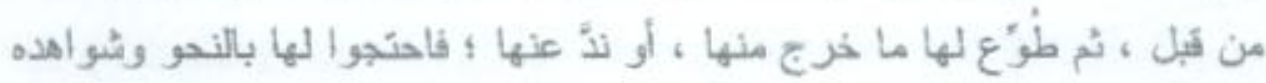
" وهذا عكس اللوضع الصحيح ؛ إذ السلامة في المنهج ، و السداد في المنطق

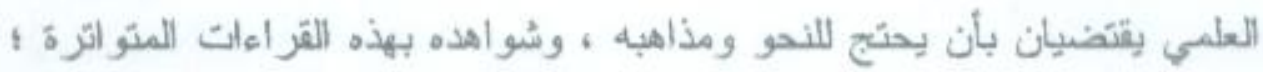

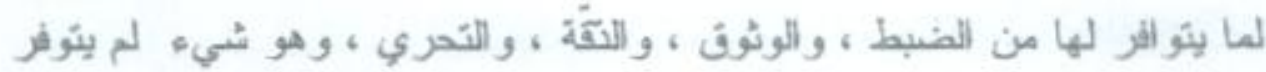

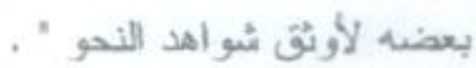

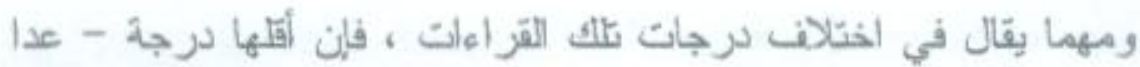

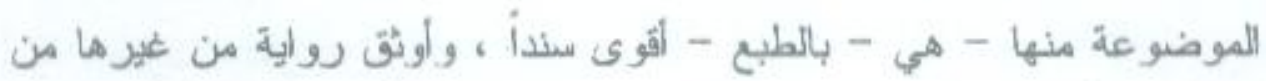

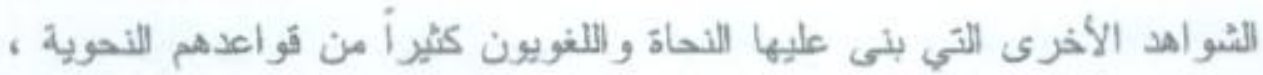
وأصولهم اللفوية .

$$
\text { النشر 1-10/ }
$$

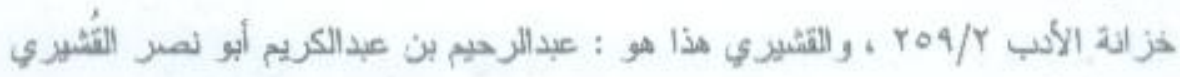

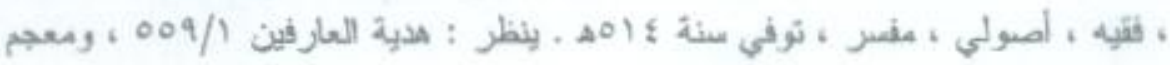

$$
\text { المولفين r. r. r. }
$$




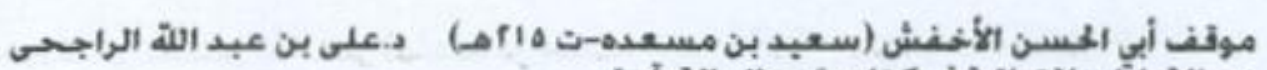

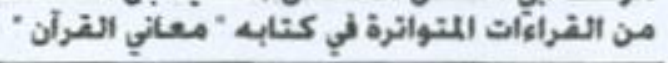

وعليه ؛ فإنه بجب البعد عن الأحكام القاطعة في المسائل -خاصة القزاعات- التي لا تقبل بطبيعنها القطع أو الجزم ؛ وذلك لقيامها على ركن الرواية و السماع، و اللغة - كما هو معلوم - رواياتها كثيرة ، وطرقها متعددة ،

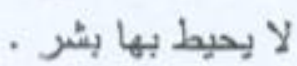
ومن رام السلامة ؛ فليعد إلى منهج يقوم على جواز الترجيح بين القر اعات القز آنية ؛ إذ فيها - كما قال القُشيري - الفصبيح والأفصح . وذلك بتحكيم لماليب العرب المتوعة ، وموازين المعنى ، وقبله صحة

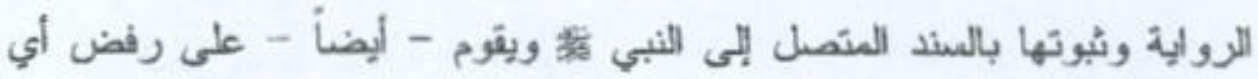

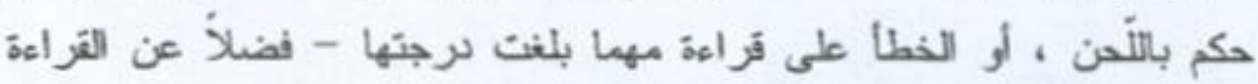

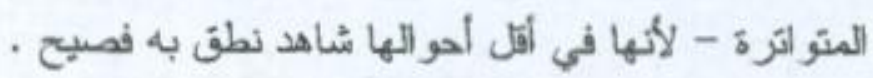




\section{المصسادر والمراجت}

1 - الابانة عن معاني القزر اهلت ، لمكي بن أبي طالب ، تحقين : د .

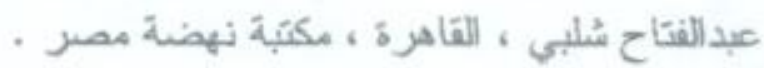
Y - إتحاف فضلاء النبشر في القزاءات الأربع عشر، لأحمد الدمياطي البناء،

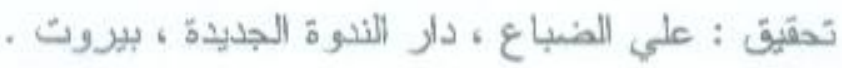

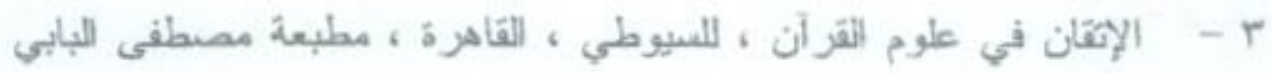

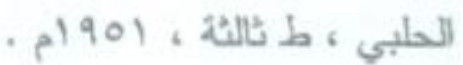

ـ - - إرشاد الفحول إلى تحقيق الحق هن علم الأصول، لمحمد بن علي

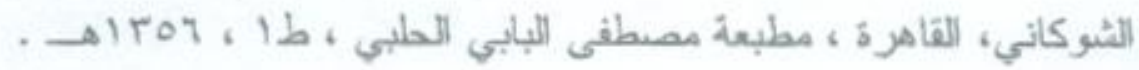

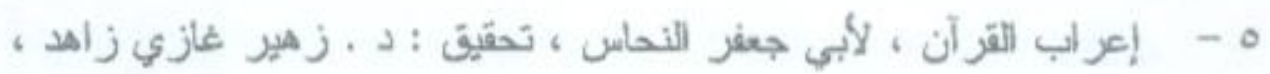

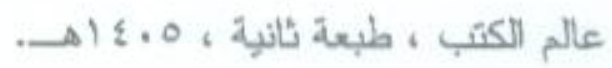
1 - - إملاء ما من به الرحمن من وجوه الإعراب و القز اعات ، للعكبري ، دار

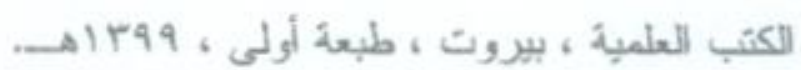

- V

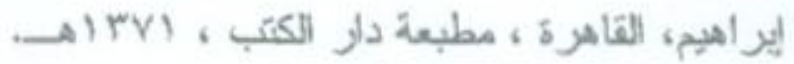
- - الانتصار لنقل القزان ، لأبي بكر الباقلاني . 9 - الإنصاف في مسانل الخلاف ، لأبي اللبركات أبن الأنباري ، تحقيق :

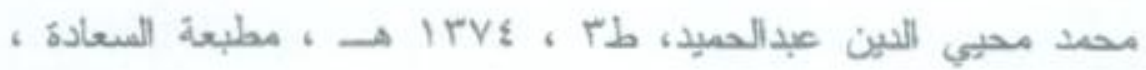
مصر

. - البحر المحيط ، لأبي حيان الأندلسي ، دار الفكر للطباعة والثثر

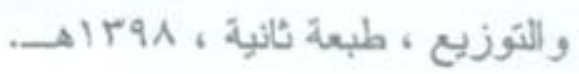




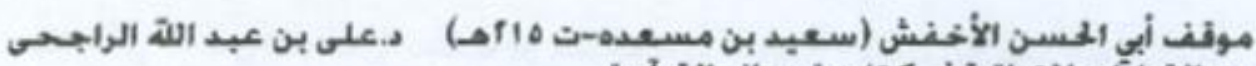

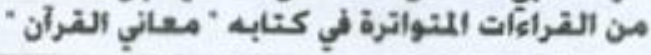

1 - البدور الزاهرة في القراعات العشر المنواتزة ، لعبد الفتًاح القاضي ؛

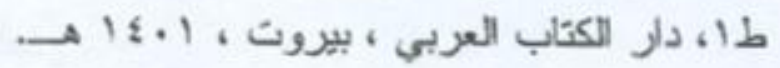

rا - البرهان في عوم القرآن ، للزركشي ، تحقيق : محمد أبو الفضل

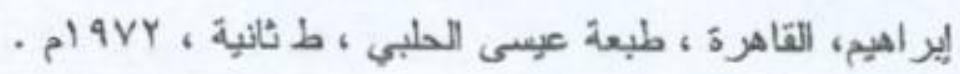

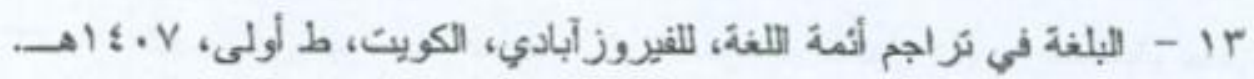
عا - تاريخ التراث العربي د . فؤاد سزكين ، ترجمة د . فهمي أبو الفضل ، ود. محمود فهي حجازي ، للقاهزة ، اللهيئة المصرية العامة للكتاب ،

$$
\text { -) } 971
$$

10 - تاريخ العلماء النحويين ، للمفضل بن محمد اللتوخي ، تحقيق : د . . عبدالفتاح للحلو ، الرياض ، جامعة الإمام معدد بن سعود الإسلامية ،

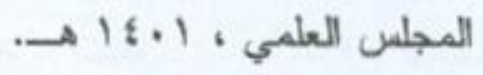

17 - 17

IV - التببان لبعض المباحث المتعلقة بالقرآن على طريث الإتان ، تأليف : طاهر الجزائري، عنابة: عبدالفتاح أبو عدة، مكتبة المطبوعات الإسلامية كلب.

11 - تهذيب اللغة ، لأبي منصور الأزهري ، تحقيق : مجموعة من الباحتين،

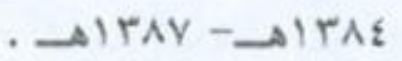

19 - - جامع البيان في تقسير القرآن ، للطبري ، بيروت ، دار المعرفة ، ط

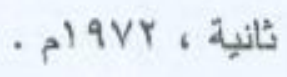

• r - لجامع لأحكام القزآن ، اللقرطبي ، تحقين : أحمد عبدالعليم البردوني ؛

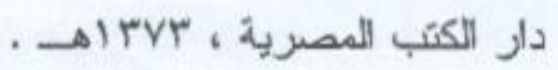




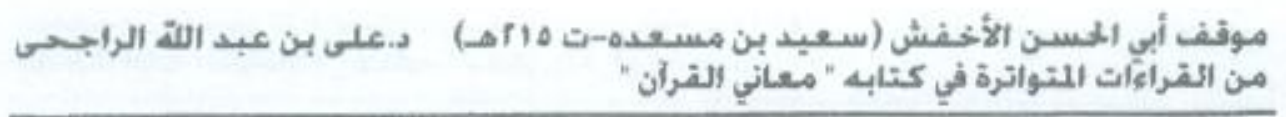

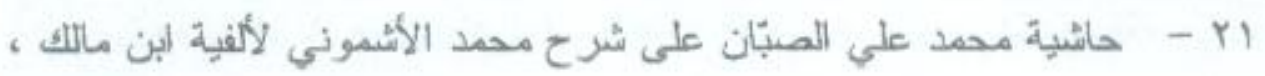

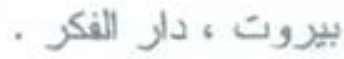

Y Y حجة القراهات ، لابن زنجلة ، تحقيق : سعيد الأفغاني ، مؤمسة

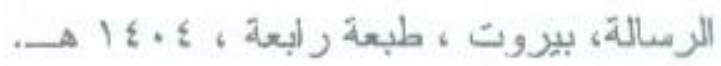

rr - الحجة في القر اهات السبع ، لابن خالويه ، تحقيق : د . عبدالعال سالم

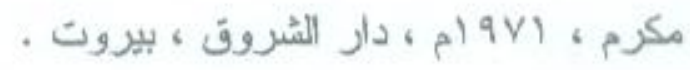

ع r - الحجة للقز أ السبعة ، لأبي علي الفارسي ، تحقيق : بدر الدين قهوجي ،

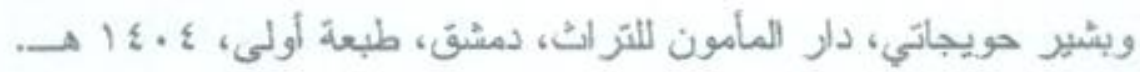

O - خزانة الأدب ولب لباب لسان العرب ، لعبدالقادر البغدادي ، تحقيق :

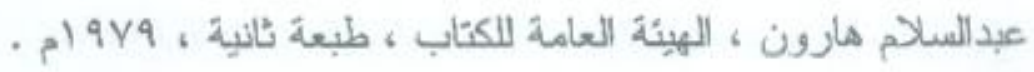
צr - السبعة في القراعلت ، لابن مجاهد ، تحقين : د . شوقي ضيف ، دار

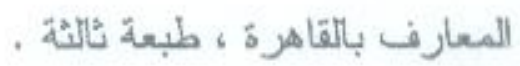

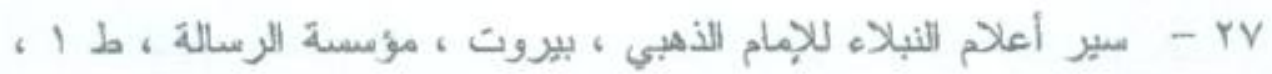
- DIE.

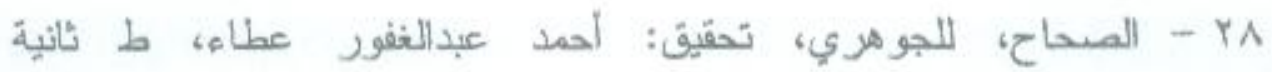
- 1 \% 99

وץ - صحيح الإملام البذاري ، عن مجموع الكنب السنتة ، نشر : شعبان قورتش، دار اللدعوة .

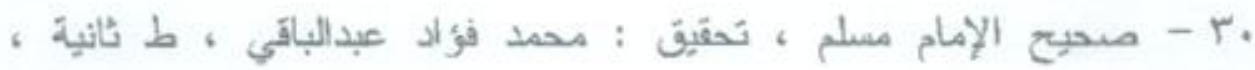

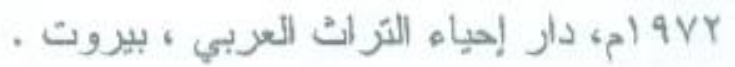

ابr - علل القراعات ، لأبي منصور الأزهري ، تحقيق : نوال الحلوة ، طبعة

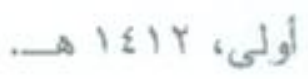




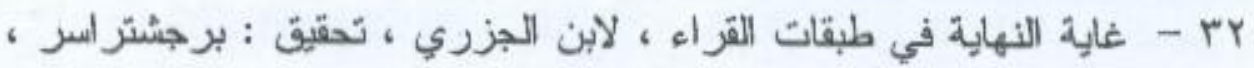

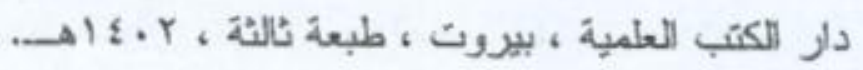

rr - غبث النفع في القر اهات المبع ، ثأليف : علي النوري الصفاقسي ، طبع

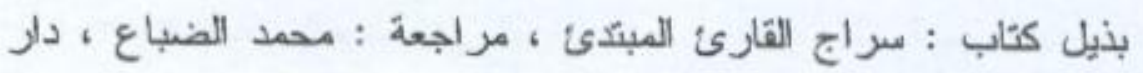

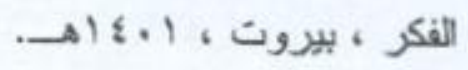

§ب - القاموس المحيط ، للفيروزآبادي ، ط المطبعة المصرية ، القاهرة ،

$$
\text { . }
$$

م - القز اءات القز آنية ، تاريخ وتعريف ، د . عبدالهادي الفضلي ، بيروت ،

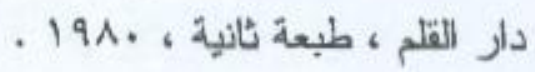

حr - القر اهات وأئزها في علوم العربية ، د . محمد سالم محيسن ، القاهرة ،

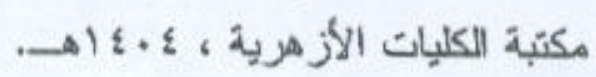

- rV

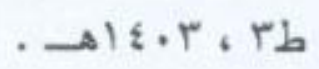

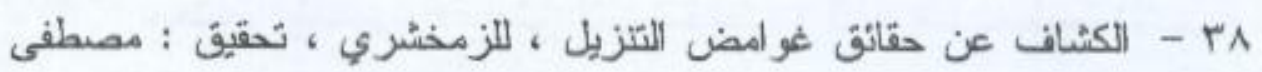

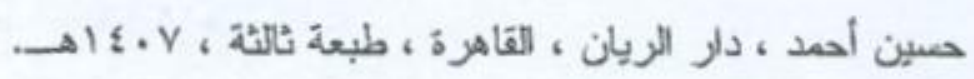

وبr - كشف الأسرار عن أصول النردوي ، تأليف : علاء اللين بن أحمد

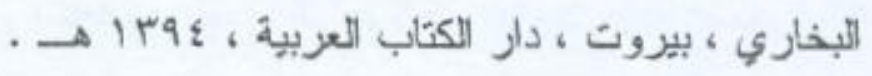

•ـ - الكشف عن وجوه القر اءت السبع و عللها وحججها ، لمكي بن أبي طالب

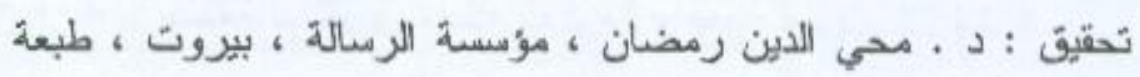

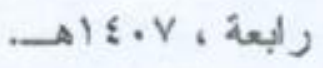
ا؟ - لسان العرب ، لابن منظور ، بيروت ، دار صادر · 


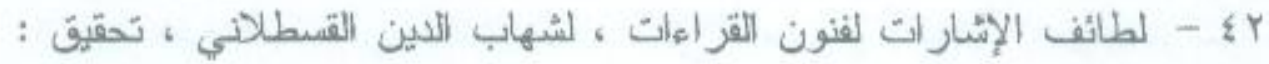
عامر السبد عثمان ، ود . عبدالصبور مُاهين ، القاهرة ، المجلس

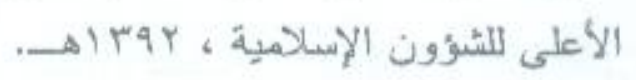

باء - - اللهجات العربية في اللتزاث ، د . أحمد علم اللين الجندي ، مطلابع الهيئة المصرية العامة للكتاب ، 970 ام ، القاهرة .

؟؛ - المبسوط في القر اعات العشر ، لأبي بكر أحمد بن الحسين الأصبهاني ،

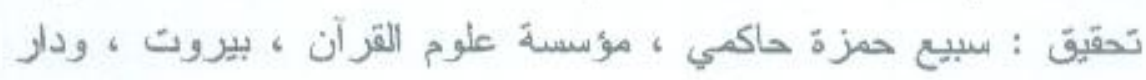

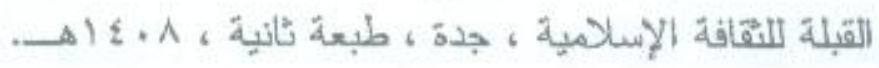

0ـ - المحنسب في تبيين وجوه شواذ القراءات و الإيضاح عنها ، لابن جني ،

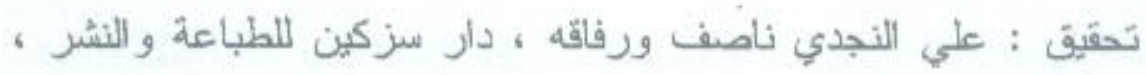

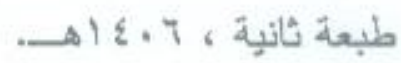

1؛ - مختصر في شواذ القرآن ، لابن خالوبيه ، نشره : براجشتراسر ،

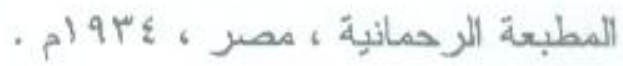

EV - مختصر المنتهى الأصولي لابن الحاجب ، القاهرة ، المطبعة الأميرية ، -

1ـ - المرشد الوجيز إلى علىم تكلق بالكتاب التزيز ، تأليف : أبي شامة

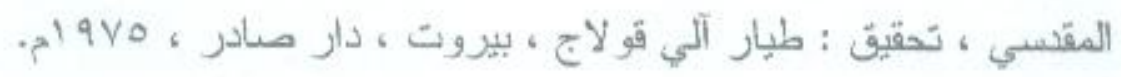

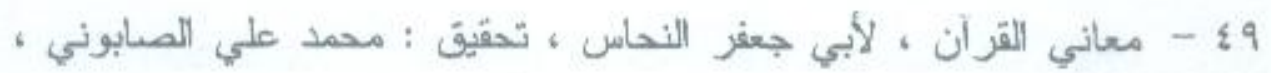

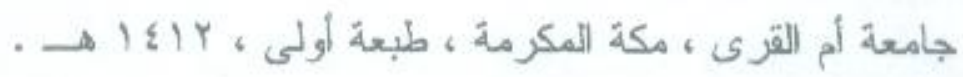
0 - معاني القزآن ، للفر اء ، تحقيق : أحمد يوسنف نجاتي ، ومحمد علي النجار ، دار المرور ، بيروت . 


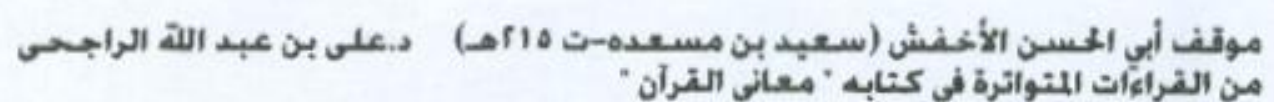

10 - دعاني القرآن وإعرابه ، لأبي إبحاق الزجاج ، تحفين : د . عبدالجليل

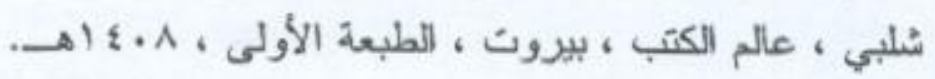

ror - معجم المؤلفين، لعمر رضا كحالة، دار إحياء الثراث العربيى ، بيروت. م - معرفة القراه آكبل على لطبقات والأعصلر،لذهبي، تحقيف: شعيب

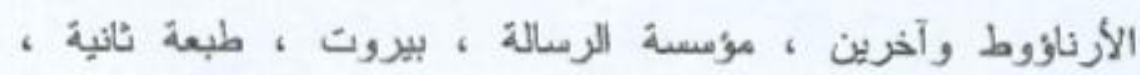
. $1 \leqslant \cdot \hat{A}$

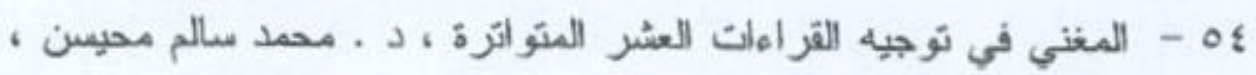

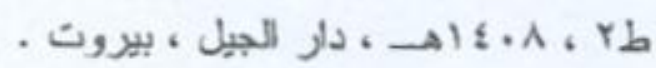

هـ - منجد المقرئن ، لابن الجزري ، تحقيق د : عبدالحي الفرماوي ، القاهرة ، مكتبة جمهرية هصر ،

7ه - اللحو وكتب التفقير ، لـ د . إير اهيم رفيدة ، الدار الجماهربة النثر ،

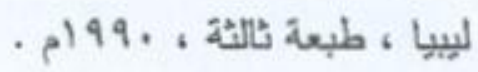

OV - الثشر في القر أهات العشر، لابن الجزري، تحقيف : محمد أحمد دهمان،

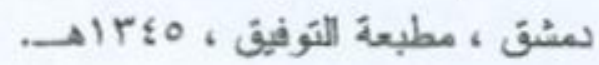
ه - هدية العارفين ، لإسماعيل البغدادي الستابول ، 901 ام. 9ه - وفيات الأعبان و أثباه لبناء الزمان ، للقاضي شُس الدين أحمد بن محمد بن خلكان ، تحفيق : محمد محيبي الدن عبدالحمبد ، طا ، القاهرة ، - A IrVT 
